\title{
Political leadership and the quality of public goods and services: Does religion matter?
}

\author{
Aloys L. Prinz ${ }^{1}$ (D) Christian J. Sander ${ }^{1}$
}

Received: 1 April 2020 / Accepted: 22 August 2020 / Published online: 9 September 2020

(c) The Author(s) 2020

\begin{abstract}
Despite some indications to the contrary, religion still plays an important role in contemporary society. In this paper, the association between religion and the quality of public goods and services, measured by the so-called "delivery quality" index of the Worldwide Governance Indicators project, is empirically investigated. Besides religion, different political regimes may also have a crucial impact on the quality of public goods and services. In the paper, a distinction is made between theocratic, autocratic and democratic systems. It is hypothesized that the delivery quality is lower in theocratic and autocratic regimes than in democracies. In addition, religious diversity may enhance the quality of public goods and services in otherwise autocratic and democratic regimes. The level of religious goods and services provision should be lower in religiously diverse societies, because the costs of these goods are higher due to a lack of economies of scale. This may leave more potential for the provision of high-quality public goods and services by the state. These hypotheses are tested empirically with data from 190 countries. The empirical estimates confirm that both theocratic and autocratic regimes provide lower average delivery quality than democracies. Furthermore, a positive association of religious leadership with delivery quality is found in strict autocracies. Greater religious diversity is thus linked to a better quality of pubic goods and services in democracies, but not in autocracies.
\end{abstract}

Keywords Quality of public goods and services · Democracy · Autocracy · Religious leadership · Religious diversity

JEL Classification D72 $\cdot \mathrm{H} 11 \cdot \mathrm{H} 41 \cdot \mathrm{Z} 12$

Aloys L. Prinz

aloys.prinz@wiwi.uni-muenster.de

1 Institute of Public Economics, University of Münster, Wilmergasse 6-8, 48143 Münster, Germany 


\section{Introduction}

As a reaction to citizens' dissatisfaction with the political leadership in Saudi Arabia, the new crown prince, Muhammad bin Salman, announced a series of reforms for modernizing the state and reducing the influence of religious fundamentalists (Lacroix 2019). Meanwhile, protesters in Iran also demand restrictions on muslim clerics' say in political issues (Abdoh-Tabrizi and Shahi 2020). In this paper, we engage with the general question of how the interaction of religion with the political system of a country is associated with government performance. More precisely, we present a comparative analysis of the quality of public goods and services in alternative political regimes. We thereby differentiate between religious and non-religious forms of non-democratic leadership. Furthermore, we provide an argument linking religious diversity to the quality of public goods and services.

It is well-known that religions, as cultural institutions, have survived because of their significance in personal life, as well as in enabling an effective community. Although it is difficult to define religion in all its aspects, it seems generally accepted that religion is part of culture, understood as a framework of shared values and implicit rule systems (Kasper et al. 2012, p. 178). Religion entails spiritual and transcendental beliefs and provides a system of values and behavioral norms. As mental and social constructs, ${ }^{1}$ religions influence both preferences and behavior. ${ }^{2}$

From an institutional economics viewpoint, religions are often considered as formal organizations rather than institutions at the level of society, because they are purpose-oriented and have a hierarchical structure (see the definition of organizations in Kasper et al. 2012, p. 108). Nonetheless, within these organizations, there are institutionalized formal and informal rules for social behavior; the latter indicating that religions may be interpreted as both organizations and institutions (see Kasper et al. 2012, pp. 106, $108 \mathrm{ff}$. for a definition of institutions and their different forms). As organizations with institutionalized rules, religions can become politically relevant or even dominant. This is the key point for analysis in this paper. Religions as organizations may be theocracies, defined below as authoritarian political systems that are led by individuals at the apex of a religious elite. The legitimization of this kind of leadership comes at least partially from the religion itself. In this respect it differs clearly from other autocratic political systems and from democracies. While Western societies developed their institutions mainly independently of, or even in conflict with religions, the separation of politics and religion, prevalent in contemporary Western societies, is not common in other parts of the world. In Europe, the separation of the church and the state started in the medieval age (Pollack et al. 2013). As indicated by the Thirty Years' War (1618-1648) in Europe, it took a long time for this separation to be completed.

From a global viewpoint, however, the separation of religion and politics remains incomplete. For instance, countries like Saudi Arabia and Iran, but also the Vatican,

\footnotetext{
${ }^{1}$ According to Searle (2010, p. 91), churches are so-called special-purpose institutions.

${ }^{2}$ See Boyer $(1992,2001)$ and Lehmann (2005) for an explanation of religion from the perspective of cognitive psychology.
} 
are still examples of theocracies, at least according to the Encyclopaedia Britannica (2020). A theocracy may be defined by three key constituents: the government consists of divinely guided leaders, government leaders are clerical persons and the legal system originates from religious laws (Encyclopaedia Britannica 2020). Although some democratic elements, such as general parliamentary elections, are also established in theocratic countries, they do not play a prominent role in politics. Put differently, theocratic countries are those that are not politically secularized. Moreover, according to this definition, theocracies cannot be considered democracies. In a democracy, the legitimization of political power is granted for a certain period of time by the country's electorate. This contradicts and runs contrary to the devine origin of political power in a theocracy.

In this paper, the association between religious leadership and religious diversity and the quality of public goods and services is analyzed. Based on three archetypical forms of society, i.e. a theocratic regime with religious leadership, an autocratic regime, and a democracy, we analyze the quality of public goods and services in a simple Buchanan-Brennan Leviathan framework. The respective political leaders provide public goods and services that are paid for by taxes in order to legitimize their leadership in all regimes. Furthermore, all leaders appropriate some private goods for themselves and their political supporters. However, the extent and legitimization of the political establishment differ between regimes. Our theoretical framework implies that the population is less satisfied with the quality-adjusted level of public goods and services in theocratic or autocratic regimes than in democratic regimes. In addition, theocratic leaders provide religious goods and services to legitimize their rule, whereas in autocratic and democratic regimes these goods are provided privately. The private provision of religious public goods in non-theocracies may reduce the perceived quality of public goods and services, which are supplied by the state, as these goods are - at least in some parts - substitutes for each other. For instance, social welfare, health care, kindergartens or schools may be provided by religious groups or by the state. We argue that the private provision of religious public goods is higher in countries with greater religious homogeneity, due to economies of scale. Consequently, religious diversity may reduce the private provision of religious goods and increase the perceived quality of public goods provided by the state, since the state's supply is less contested.

We test the theoretical differences in the quality of public goods and services by using data of the Worldwide Governance Indicators (WGI) project in 190 countries, as well as data on the religious diversity and political system of these states. In particular, the so-called delivery quality indicator is applied as a measure of the quality of public goods and services in the included states. The religious diversity within countries and their political regime are considered as the crucial determinants of delivery quality. As an innovation, we combine the dichotomous democracy-autocracy regime data provided by Bjørnskov and Rode (2020), with information about the separation of religion and state, in order to categorize a country's political regime as either theocratic, autocratic, or democratic. The empirical analysis shows that the political system does matter indeed for the provision of public goods and services. All specifications demonstrate that theocratic and autocratic regimes are associated with a lower average delivery quality than democracies. Delivery quality 
does not differ systematically between theocratic and autocratic societies. However, there is a statistically significant positive association between religious leadership and delivery quality in strict autocracies (polity 2 range from -10 to -2 ). Higher religious diversity is linked to higher levels of delivery quality in democracies only.

The remainder of the paper is structured as follows. In Sect. 2, the relevant literature is reviewed. Section 3 derives the hypotheses. The empirical investigation is presented in Sects. 4 and 5. Section 6 concludes.

\section{Literature review}

Religions and religiosity are established topics within the academic economics literature. Max Weber's "The Protestant Ethic and the Spirit of Capitalism", first published in 1905, for instance, was an early contribution on the significance of religiously motivated economic behavior. Meanwhile, many connections between religion and economic variables have been investigated, including religion and economic welfare (Heath et al. 1995), religion and economic growth (e.g., Barro and McClearly 2003), religiosity, property rights and the rule of law (Berggren and Bjørnskov 2013), religion and economic attitudes (Guiso et al. 2003), and extending to religiosity and life satisfaction (Okulicz-Kozaryn 2010), as well as religion and democracy (Dima et al. 2014) or religion and economic freedom (Hillman and Potrafke 2018). Even attitudes to the Euro and the Euro crisis were found to be related to religious confessions in Germany, with protestants being more skeptical than non-protestants (Chadi and Krapf 2017).

In all these studies, religion and religiosity play a role, positive as well as negative. As stated by Okulicz-Kozaryn (2010), most of the effects depend on the social and political setting of religion. For instance, democracies (religious or not) may conduct quite different public policies to non-democracies (theocracies or autocracies) (Mulligan et al. 2004).

The latter is also the preliminary assumption for this paper. We reason that competition between religions within societies, as well as the interaction of religions and the political system, matter for the provision quality and quantity of public goods and services. It is widely accepted in the economics literature that not only the quantity but also the quality of public goods and services (see, e.g., Walsh 1991), as well as the quality of public governance (see, e.g., Bovaird and Löffler 2003), are of relevance for both citizens and society. They are, therefore, topics for economic analysis.

Perhaps the most important contribution on public good provision under different political incentives is Lizzeri and Persico (2001). The authors formalize a game theoretic model for the provision of public goods in a so-called 'winner-take-all' democratic system and a 'proportional system'. In the former electoral system, all political power rents, called "spoils of office", are appropriated by the electoral winner. In the latter system, the electoral winning parties share the "spoils of office" proportionately, i.e., the candidates split the "spoils of office". The electoral candidates can only decide on either the provision of a public good or the redistribution of money. The provision of the public good creates supposedly higher welfare effects for society than redistributing money. Even with homogeneous voters, the supply 
of the public good occurs in a proportional system more frequently than in one of 'winner-take-all'. In both political systems, a trade-off exists between the value of the public good and the redistribution of money. By splitting the power rents among candidates in the proportional system, the rent that a single candidate can spend is lower than in a 'winner-take-all' system with one candidate only. Consequently, the value of the public good becomes higher in the proportional system and will be provided more often, because it is more valuable for voters than an additional unit of redistribution.

Applying the results of the Lizzeri-Persico model seems to be restricted to democratic systems, and does not apply to political systems that are of religious or autocratic origin. Nevertheless, as indicated in a paper from Binet and Facchini (2011), the dominant religion in a country may have an effect on public spending. Although the authors find empirical support for a positive and significant effect of GDP per capita and political stability on religious freedom, they did not find an effect of religious denominations on public spending.

Besley and Ghatak (2006) found a considerable gap between governmental expenditure on public goods in developing countries and their effectiveness, since a large proportion does not reach the intended beneficiaries. The design of institutions, as well as the form of public goods provision, play a decisive role. This may be interpreted as indicating that the political and religious particularities behind the institutions have a significant influence on the quality and quantity of public goods. In a recent paper, Kammas and Sarantides (2019) find empirical evidence of more direct fiscal redistribution in non-democratic systems, whereas democratic systems provide more public goods concerning health and education.

According to Deacon (2009), dictatorships provide lower levels of certain public goods (roads, public schools and sanitation, safe water, pollution control) than democracies. The differentiation between political regimes is based on the Polity IV database that is also used as a source in this paper. Lake and Baum (2001) argue that democratic states receive lower levels of monopoly rent than non-democracies. They also find empirical support for their hypothesis.

Besley and Burgess (2002) investigate the factors that determine the responsiveness of governments to citizens' preferences. In competitive political systems, where parties and political candidates compete for political power, they show that the information, as well as the political activity of citizens, are decisive for government responsiveness to people's preferences. Expressed differently, the less competitive the electoral system, the less information is accessible by citizens, and the lower citizens' political activity, the poorer the match between people's preferences and the provision of public goods. However, as argued by Bardhan and Mookherjee (2000), the potential and actual capture of politics by vested interests may be an additional factor that influences the provision of public goods at local, as well as national levels.

A further aspect of the quality of public goods provision is discussed by Besley et al. (2004), who examine empirically the public goods provision by local Indian governments. They find that two different effects depend on the spillovers of public goods. In the case of low-spillover public goods, sharing the 'group-identity' of politicians is essential, whereas in the case of high-spillover public goods, 'residential proximity' is decisive. In addition, incentives and organizational design also matter 
for the provision of public goods (Dixit 2002; Besley and Ghatak 2003). Nevertheless, this is beyond the scope of the present paper.

The effects of the quality of public finances, of which public goods provision is an essential part, on economic growth is analyzed conceptionally and reviewed empirically for the European Union by Barrios and Schaechter (2008). This paper shows that not only the quantity and quality of public goods, but also the sustainability and stability of financing public goods are important for economic growth.

Last, but not least, Kuran and Sandholm (2008) argue that social integration policies homogenize citizens' preferences. This may be an important aspect of the supply of public goods in different political systems that are more or less homogeneous.

An indication of the relevance and significance of religions with respect to economic variables in general, and public goods in particular, comes from a paper by Barro and McClearly (2005), in which countries with state religions are considered. Surprisingly, having a state religion is in fact very stable, even when comparing the far apart years 2000 and 1900.

Owen and Videras (2007) found empirical evidence from OECD countries that religious beliefs may elicit voluntary contributions to the provision of a public good, in their case environmental quality. This is in accordance with results from Kilinç and Wagner (2015); Catholics seem to be motivated towards voluntary public goods provision through love of the others, whereas the duty to God is crucial for Muslim charitable giving. In addition, both are altruistically oriented to their respective communities (Kilinç and Wagner 2015). However, the latter is not necessarily good for the entire society. The reason is that the privately provided public goods by religions may exclude those who not belong to it. Such behavior is empirically demonstrated by Chaudhary and Rubin (2016) with Indian data.

Berman and Laitin (2008) explain by means a club model how radical religious rebels can be motivated to carry out terrorist attacks. The key is the efficient provision of local public goods by the respective voluntary organization. To deter defectors from this organization, a costly commitment is required. The respective commitment is the preparedness to carry out such attacks. The empirical analysis in Berman and Laitin (2008) supports this theory.

An essential consideration is that when the state provides public goods, the private provision of these goods may decrease. Hungerman (2005) shows that state and religious organizations behave as substitutes with respect to a welfare service change in state policy. Moreover, according to Gill and Lundsgaarde (2004), an expansion of public goods provision by the state may induce individuals to reduce their participation in spiritual activities, because the goods can be obtained without religious participation.

The Islamic origin and development of the so-called "Waqf" system is described in Kuran (2001). This allowed rich people to transfer personal wealth into a charitable foundation which provided decentralized public goods according to the intention of the donor. However, the inefficient Waqf system has now been replaced by governmental provision. Nevertheless, according to Kuran (2004), the inefficiencies of Waqf, in combination with Islamic inheritance law and the absence of the corporation as a collective type of enterprise, are at the basis of the economic underdevelopment of Islamic 
Middle East states (Kuran 2004, p. 71). It seems that over time, once functional institutions became a trap and an obstacle for economic, political and social development.

Moreover, the Waqf system has not vanished completely. In this respect, Turkey is a good example concerning the interaction of state provision and religious provision of public goods (Öktem and Erdoğan 2018). According to Öktem and Erdoğan (2018), two welfare system coexist in Turkey, an older one based on Islamic private charity, called "vecif", and a newer social pension system, run by the state. The older Islamic social assistance system provided occasional payments without any legal rights to them, whereas the new system pays pensions continuously on a legal basis. The quality of the systems seems to be quite different. In the older system, payments depend on the benevolence of the respective organization, in the newer one the claims are legally defined and hence predictable.

Although Alesina et al. (2003) find empirical evidence of connections between linguistic and ethnic diversity and growth, this does not hold for religious fractionalization. However, such fragmentation is positively related to governance quality indicators, for instance, the control of corruption, lower rates of tax evasion and higher levels of democracy and school attainment. The authors conclude that religious diversity is greater in "more tolerant countries" (Alesina et al. 2003, p. 175). By contrast, Alesina and Zhuravskaya (2011) do not find any effects of religious segregation on the quality of government indicators at the subnational level. Berggren and Bjørnskov (2013) investigate empirically whether there is an impact of the share of religious people on property rights and the rule of law, as indicators of institutional quality. They report a negative impact in democracies, but none at all in autocracies.

Binet and Facchini (2011) find that the dominant religion in a country may have an effect on public spending. Although the authors present empirical support of a positive and significant effect of GDP per capita and political stability on religious freedom, they did not present an effect of religious denominations on public spending.

Two papers emphasize empirically the role of Protestantism with respect to two very specific public goods, namely economic freedom and the Euro. Hillman and Potrafke (2018) find that Protestantism is associated with economic freedom, whereas Islam is not. Chadi and Krapf (2017) document that the fiscal crisis in the Eurozone was concentrated in Catholic countries, whereas Protestant countries were not so much involved. The authors attribute this to the Protestant fiscal ethic.

To sum up, the reviewed literature investigates several influences of political variables, as well as religious ones, on the provision of public goods and services. However, the interaction between religion and political systems and qualitative aspects of public goods and services are worth considering more thoroughly. This is of relevance, as citizens appreciate not only the quantities of theses goods and services, but also their qualitative aspects. 


\section{Religion, political leadership and the quality of public goods and services}

In this section, we develop hypotheses concerning the differences between determining the quality of public goods and services in a theocratic society, an authoritarian society and a democratic society. ${ }^{3}$ The framework for these hypotheses is the well-known Buchanan-Brennan Leviathan model (Brennan and Buchanan 1980; Wintrobe 1998, as adapted by Coşgel and Miceli 2009). A formal derivation of the hypotheses is presented in "Appendix 2".

We assume that all forms of government provide public goods and services, but possibly with different volumes and levels of quality. As it is usual in official economic and government statistics to value public goods and services in terms of their production costs, these numbers do not necessarily say anything about their quality. However, depending on the political regime, it can be hypothesized to what extent the provided quality meets citizens' preferences and expectations.

All forms of government collect taxes that are also used to finance the private consumption of government members, to a greater or lesser extent. We conjecture which form of political leadership has a higher or lower propensity to use tax revenues for private purposes.

\subsection{Theocracy}

In a theocratic society, the religious leaders decide on the level and quality of religious goods. In addition, they also determine the amount of public goods and services. Religious goods are at least partly provided as public goods and services as, for instance, evident in the form of churches, temples, mosques etc., as well as religiously oriented kindergartens and schools.

In a theocratic society it is not obvious whose preferences count for public goods and services. Theocratic leadership does not face democratic control, so that the preferences of citizens are not particularly relevant for the provision of these goods. In addition, theocratic leaders can invoke devine criteria and superior knowledge of what is good for citizens and society. A third aspect of public good provision is the fact that religious and other public goods overlap to a certain degree. Therefore, it would not be easy for citizens to complain an insufficient public goods supply that does not provide what citizens really want.

It is not obvious whether theocratic leaders demand higher or lower shares of taxes for their own consumption in comparison to secular autocratic regimes. However, because of the lack of democratic control, leaders' private consumption out of tax revenue can be assumed to be larger than in a democratic regime.

\footnotetext{
3 See Deacon (2009) for an elaborate model of public good provision under different political regimes, but without religious leadership.
} 


\subsection{Autocracy}

In an authoritarian society, the political leadership generally uses tax revenue to "buy" the loyalty of a subgroup of the population whose support is necessary to remain in power, the so-called winning (autocratic) coalition (Bueno de Mesquita et al. 2003). Autocratic regimes also finance commonly part of their leadership's private consumption by taxes. Moreover, the provision of public goods and services is employed to legitimize the regime.

In contrast to theocratic regimes, autocratic ones do not provide religious goods. Unless the regime oppresses certain religions, religious goods are provided privately. Note, however, that the privately provided level of religious goods may decline with increasing religious homogeneity. Competition between religious groups diminishes the economies of scale and scope, which increases the costs of providing religious goods. Given that the demand for religious goods depends negatively on the price, the level of religious goods provision will decline.

It can be conjectured that the use of tax revenue to finance private consumption by the political leadership is at its maximum in an autocratic political regime. It is not only that democratic control is lacking, but there are also no moralistic or religious constraints. It can therefore be assumed that citizens are left with their reservation utility (i.e., the minimum required for citizens to work and pay taxes).

The lack of democratic control, as well as of societal homogeneity, may render an autocratic leadership free to provide those public goods and services that stabilize their own stay in power. Public goods may not be provided for the general public, but primarily for those people who are necessary for the security of the autocratic system. For instance, a strong military force with system-friendly leaders may consume a large part of tax revenue, and so to supportive secret police.

The financing of private consumption by taxes, the need for a strong military and a large secret police may thus reduce the quality of public goods and services for the citizens, because of a concomitant lack of resources.

\subsection{Democracy}

In a democratic society, the quality of public goods and services are strategic variables for gaining support from citizens for the political leadership. Candidates as well as political parties struggle in coming to power with the promise of supplying certain levels of public goods and services, for all citizens in general and for their constituency in particular. As in autocracies, religious goods are provided privately. An exception are states where the head(s) of state is (are) required to belong to a certain religious organization or affiliation. In such states, public religious goods may also be supplied by the state and financed by taxes.

Democratic control of the behavior of the political leadership prevails on two levels. First of all, citizens vote in general elections and may easily change the political leadership. Since citizens may also easily observe and recognize the provided level and quality of public goods and services, they will have an influence in elections. 
Moreover, politicians and political parties compete with each other to gain (or stay in) power. In this way the provision of public goods and services and their quality is the focus of these people and organizations.

Nevertheless, even in a democratic political regime, the political leadership uses part of tax revenue to finance their private consumption. Since all parties and politicians behave the same way in this respect, the public financing of private consumption also exists in this regime. However, a restriction to this use of tax revenue arises from the press and citizen organizations that may criticize escalating expenditures for such purposes.

Finally, it is necessary to consider whether religious diversity affects the quality of public goods and services. As argued above, the more diverse religions in a society, the lower the level of religious goods provided, because of decreasing economies of scale and scope. Moreover, if the state is not responsible for religious goods provision, more resources from a constant level of tax revenue can be used to finance better public goods and services.

From this short analysis, we can derive the following two hypotheses that will be tested in the next two sections:

Hypothesis 1 The quality of public goods and services is larger in democracies than in both theocracies and autocracies. In addition, the quality of public goods and services in theocracies is either larger than or equal to the level in autocracies.

Hypothesis 2 In autocratic and democratic regimes, the quality of public goods and services increases with increasing religious diversity.

\section{Description of the data}

\subsection{Delivery quality as a proxy for the quality of public goods and services}

The Worldwide Governance Indicators (WGI) project reports six indicators of governance, namely government effectiveness, regulatory quality, rule of law, control of corruption, voice and accountability, political stability and absence of violence. According to Alesina and Zhuravskaya (2011, p. 1884) the WGI are "standard measures of the quality of government". All indicators are aggregates of several hundred individual underlying variables that capture survey responses and experts' views from a variety of sources. The WGI range from -2.5 to 2.5 and increase with government performance. ${ }^{4}$ To disentangle a government's democratic quality from that of the public goods and services it provides, we use the average of the first four indicators, defined as "delivery quality" by Helliwell and Huang (2008), as our proxy for the quality of public goods and services in a country. According to Helliwell and Huang $(2008$, p. 601), delivery quality captures the "efficacy of the delivery of government services" which is closely related to the subjective well-being of citizens,

\footnotetext{
${ }^{4}$ For a detailed description of the WGI methodology, see Kaufmann et al. (2010).
} 
Table 1 Countries with highest and lowest average delivery quality from 1996 to 2017

\begin{tabular}{ll}
\hline Country & Delivery quality \\
\hline Finland & 2.032 \\
Denmark & 2.027 \\
Singapore & 1.973 \\
New Zealand & 1.949 \\
Sweden & 1.931 \\
- & - \\
Afghanistan & -1.539 \\
Turkmenistan & -1.539 \\
Congo (Kinshasa) & -1.564 \\
South Sudan & -1.738 \\
Somalia & -2.098 \\
\hline
\end{tabular}

Data source The World Bank

whereas the two other indicators more or less capture the level of democracy. We focus on citizen perceptions of the quality of public goods and services by using delivery quality for our analysis, rather than government expenditures. Data for delivery quality is available for 203 countries, covering 19 years $(1996,1998,2000$ and 2002-2017) with a total of 3769 observations. ${ }^{5}$ Table 1 lists countries with the highest and lowest average delivery quality over this period. We hypothesize that the quality of public goods and services, measured by delivery quality, is linked to the political regime that provides them.

\subsection{Political regimes}

We combine the dichotomous regime data, provided by Bjørnskov and Rode (2020), with information on the separation of religion and state in a country, in order to categorize its political regime as either theocratic, autocratic, or democratic. Bjørnskov and Rode (2020) updated and expanded the Cheibub et al. (2010) database, using a minimalist definition of democracy. They categorized a country as a democracy if free and fair elections enable peaceful leadership turnover. ${ }^{6}$ We follow Bjørnskov and Rode (2020) in their distinction between democratic and non-democratic regimes, but as a novelty, we classify non-democracies as theocratic, if they are characterized by an absence of secularization, and autocratic otherwise. We apply the following criteria for the separation of religion and state. We use information on religious requirements for heads of state, provided by Theodorou (2014), who analyzes constitutions or basic laws based on the Comparative Constitutions Project.

\footnotetext{
5 Delivery quality was calculated only if data on all of the four underlying indicators was available.

${ }^{6}$ Bjørnskov and Rode (2020) use the variable democracy, which is a dummy variable, taking the value 1 if a country is classified as democratic in a specific year.
} 
Theodorou lists countries in which heads of state are required to have a particular religious affiliation (coded as religious leader in our data). ${ }^{7}$ As a robustness check, we also apply an alternative measure for the separation of religion and state from the Religion and State Dataset (RAS3), provided by Fox (2017) in Sect. 5.3.2.

Using this classification scheme, our sample consists of 137 democratic, 81 autocratic and 21 theocratic country-regimes. Since the democracy variable is not available for 72 country-years, we are left with 3697 observations of 198 different countries. The political regime of six countries with religious requirements for heads of state changed over the period of our analysis. As periods of transition from one regime to another might be accompanied by political unrest which is likely to affect the level of satisfaction with public good provision, we provide results excluding and not excluding transition countries.

\subsection{Religious diversity}

We measure religious diversity within a country with the so-called Religious Diversity Index (rdi), published by the Pew Research Center (2014). The rdi is an inverted version of the Herfindahl-Hirshman Index, and is based on the shares of major world religions (Buddhism, Christianity, folk or traditional religions, Hinduism, Islam, Judaism, other religions, and the religiously unaffiliated) for the year $2010 .^{8}$ Its scale ranges from 0 to 10 , whereby higher values indicate more religiously diverse societies. Since we do not have data for other years, and since denomination shares might change only gradually over time, we assume that the shares remain at the 2010 level for the following analysis.

\subsection{Control variables}

Other variables that are likely to influence delivery quality and regime type are from The World Bank (WB). We control for a country's GDP per capita in purchasing power parity at constant 2011 international dollar prices (WB-indicator "NY.GDP.PCAP.PP.KD"), total population (WB-indicator "SP.POP.TOTL"), total natural resources rents in percentage of GDP (WB-indicator "NY.GDP.TOTL.RT.ZS"), and tax revenue in percentage of GDP (WB-indicator "GC.TAX.TOTL.GD.ZS"). Tax revenue refers to compulsory transfers to the central government, excluding most social security contributions and might be regarded as the price of public goods and services. Not all control variables are available for all countries and/or years. Adding GDP per capita results in a loss of 187 observations. Total population size is not available for 44 observations, but since the missing values for population coincide with missing values of GDP per capita, no additional information is lost by adding population size simultaneously with GDP. Data on total natural resources rents in percentage of GDP are not available for 117 observations;

\footnotetext{
${ }^{7}$ Countries with religious requirements for ceremonial monarchs are excluded. As the influence of ceremonial monarchs on operational politics, particularly on public good and service provision, is limited, the classification of these countries as theocratic does not seem suitable.

${ }^{8}$ Anckar (2011) uses a similar differentiation of religions, employing so-called cosmo religions (Barrett et al. 2001).
} 
Table 2 Descriptive statistics

\begin{tabular}{llllll}
\hline & N & Mean & SD & Min & Max \\
\hline Delivery quality & 3769 & -0.015 & 0.961 & -2.381 & 2.185 \\
Democracy & 3697 & 0.604 & 0.489 & 0.000 & 1.000 \\
Religious leader & 3769 & 0.111 & 0.314 & 0.000 & 1.000 \\
Religious diversity & 3769 & 3.069 & 2.217 & 0.000 & 9.000 \\
GDP per capita & 3540 & 17,187 & 19,876 & 468 & 134,960 \\
Population in million & 3725 & 34.074 & 130.863 & 0.009 & 1386.395 \\
Natural resources & 3651 & 7.795 & 12.136 & 0.000 & 84.240 \\
Tax revenue & 2331 & 17.052 & 7.267 & 0.0001 & 62.859 \\
\hline
\end{tabular}

Bjørnskov and Rode (2020) provide the democracy variable. Religious leader is a dummy variable indicating countries with religious requirements for heads of state, listed by Theodorou (2014). The data on religious diversity are from the Pew Research Center (2014)

Data source Data on delivery quality, GDP per capita, population in millions, natural resources, and tax revenue are provided by The World Bank

adding them simultaneously to the variables above results in the loss of 29 observations. Tax revenue is missing for 1379 observations, which accounts for $37 \%$ of our observations. It is noteworthy that average delivery quality for observations with missing tax revenue values is -0.438 , compared to 0.221 for complete observations. Hence, regression results with tax revenue as an explanatory variable might be biased and should be interpreted with caution. The descriptive statistics of the variables is provided in Table 2.

\subsection{Descriptive statistics grouped by political categorization}

Table 3 presents descriptive statics grouped by political categorization. Depicted are group means of all complete sets of observations. The number of countries and observations for each regime type summarize the availability of the variables listed above. Average delivery quality and tax revenue in percentage of GDP are highest in democracies, followed by theocratic and then autocratic societies. Surprisingly, mean GDP per capita is highest in theocratic societies followed by democracies. This might be explained partly by high rents from natural resources, since total natural resources rents in percentage of GDP is highest in theocratic, followed by autocratic and democratic societies. Religious diversity is highest in autocratic regimes, followed by democracies. Unsurprisingly, religious diversity is lowest in countries classified as theocratic.

\section{Empirical analysis}

\subsection{Political regimes and the quality of public goods and services in a cross-country model}

We start our empirical analysis by estimating the following basic cross-country model: 
Table 3 Descriptive statistics grouped by political categorization

\begin{tabular}{llll}
\hline Political categorization/variable & Autocratic & Democratic & Theocratic \\
\hline Delivery quality & -0.615 & 0.330 & -0.385 \\
Religious leader & 0.000 & 0.034 & 1.000 \\
Religious diversity & 3.638 & 3.022 & 1.769 \\
Number of countries & 81 & 137 & 21 \\
Observations & 1143 & 2232 & 322 \\
GDP per capita & 12582 & 18696 & 24871 \\
Population in millions & 43.199 & 33.707 & 23.647 \\
Number of countries & 79 & 132 & 19 \\
Observations & 1023 & 1665 & 239 \\
Natural resources & 13.542 & 4.091 & 16.720 \\
Number of countries & 79 & 132 & 19 \\
Observations & 1081 & 2121 & 279 \\
Tax revenue & 14.525 & 18.302 & 14.706 \\
Number of countries & 54 & 111 & 16 \\
Observations & 548 & 1593 & 174 \\
\hline
\end{tabular}

Religious leader is a dummy variable indicating countries with religious requirements for heads of state, as listed by Theodorou (2014). The data on religious diversity are from the Pew Research Center (2014). The political categorization of a country is our own. We regard countries as theocratic if they are classified as non-democratic by Bjørnskov and Rode (2020) and the constitution requires the head of state to have a certain religion, according to Theodorou (2014). All other countries are classified as autocratic or democratic, according to the Bjørnskov and Rode (2020) dataset. The number of countries and observations summarize the availability of the variables listed above

Data source Data on delivery quality, GDP per capita, population in millions, natural resources, and tax revenue are provided by The World Bank

$$
\begin{aligned}
\text { delivery quality }_{i}= & \alpha+\beta_{1} \cdot \text { democratic }_{i}+\beta_{2} \cdot \text { theocratic }_{i} \\
& +\beta_{3} \cdot \text { religious diversity }_{i}+\text { controls }_{i}+e_{i}
\end{aligned}
$$

Delivery quality ${ }_{i}$ is the proxy variable for the quality of public goods and services in country $i$. Democratic ${ }_{i}$ is a dummy variable that indicates whether country $i$ is classified as democratic. Theocratic ${ }_{i}$ indicates theocratic leadership in country $i$. Our reference political system is autocratic. Hence, the difference in delivery quality associated with democratic leadership is measured by $\beta_{1}$, whereas $\beta_{2}$ captures the differences between theocratic and autocratic regimes. The link between religious diversity and delivery quality is measured by $\beta_{3}$. Controls consist of other variables that are likely to influence satisfaction with public goods and services and regime type, including logarithmized GDP per capita, logarithmized population size, as well as total natural resources rents, and tax revenue, both in percentage of GDP.

We use three different (sub)samples. The all countries sample contains country-averages for our entire data set. Countries that experienced regime changes are classified according to the political regime they had for the majority of years in the period covered. Since regime changes might be accompanied by political 
Table 4 Delivery quality, political regime and religious diversity: cross-country OLS estimates

\begin{tabular}{|c|c|c|c|c|c|c|}
\hline & \multicolumn{6}{|c|}{ Dependent variable: delivery quality } \\
\hline & \multirow{2}{*}{\multicolumn{2}{|c|}{ All countries }} & \multicolumn{4}{|l|}{ Sample } \\
\hline & & & \multicolumn{2}{|c|}{ No transition countries } & \multicolumn{2}{|l|}{ Year 2010} \\
\hline Democratic & $\begin{array}{l}0.288 * * * \\
(0.087)\end{array}$ & $\begin{array}{l}0.280 \text { *** } \\
(0.095)\end{array}$ & $\begin{array}{l}0.399 * * * \\
(0.106)\end{array}$ & $\begin{array}{l}0.311 * * \\
(0.128)\end{array}$ & $\begin{array}{l}0.330 * * * \\
(0.096)\end{array}$ & $\begin{array}{l}0.411 * * * \\
(0.121)\end{array}$ \\
\hline Theocratic & $\begin{array}{l}0.086 \\
(0.136)\end{array}$ & $\begin{array}{l}-0.033 \\
(0.155)\end{array}$ & $\begin{array}{l}0.065 \\
(0.148)\end{array}$ & $\begin{array}{l}-0.049 \\
(0.187)\end{array}$ & $\begin{array}{l}0.137 \\
(0.164)\end{array}$ & $\begin{array}{l}0.096 \\
(0.198)\end{array}$ \\
\hline Religious diversity & $\begin{array}{l}0.057 * * * \\
(0.016)\end{array}$ & $\begin{array}{l}0.057 * * * \\
(0.017)\end{array}$ & $\begin{array}{l}0.055^{* * * *} \\
(0.018)\end{array}$ & $\begin{array}{l}0.055 * * * \\
(0.020)\end{array}$ & $\begin{array}{l}0.067 * * * \\
(0.017)\end{array}$ & $\begin{array}{l}0.071 * * * \\
(0.020)\end{array}$ \\
\hline Log GDP per capita & $\begin{array}{l}0.513 * * * \\
(0.031)\end{array}$ & $\begin{array}{l}0.499 * * * \\
(0.035)\end{array}$ & $\begin{array}{l}0.531 * * * \\
(0.037)\end{array}$ & $\begin{array}{l}0.526 * * * \\
(0.044)\end{array}$ & $\begin{array}{l}0.508 * * * \\
(0.034)\end{array}$ & $\begin{array}{l}0.508 * * * \\
(0.042)\end{array}$ \\
\hline Log population & $\begin{array}{l}-0.014 \\
(0.015)\end{array}$ & $\begin{array}{l}0.010 \\
(0.018)\end{array}$ & $\begin{array}{l}0.003 \\
(0.018)\end{array}$ & $\begin{array}{l}0.020 \\
(0.021)\end{array}$ & $\begin{array}{l}-0.024 \\
(0.016)\end{array}$ & $\begin{array}{l}0.001 \\
(0.020)\end{array}$ \\
\hline Natural resources & $\begin{array}{l}-0.025^{* * * *} \\
(0.003)\end{array}$ & $\begin{array}{l}-0.019 * * * \\
(0.004)\end{array}$ & $\begin{array}{l}-0.025^{* * * *} \\
(0.003)\end{array}$ & $\begin{array}{l}-0.020^{* * * *} \\
(0.004)\end{array}$ & $\begin{array}{l}-0.022 * * * \\
(0.003)\end{array}$ & $\begin{array}{l}-0.017 * * * \\
(0.004)\end{array}$ \\
\hline Tax revenue & & $\begin{array}{l}0.022 * * * \\
(0.006)\end{array}$ & & $\begin{array}{l}0.022 * * * \\
(0.007)\end{array}$ & & $\begin{array}{l}0.018 * * \\
(0.007)\end{array}$ \\
\hline Constant & $\begin{array}{l}-4.340^{* * * *} \\
(0.385)\end{array}$ & $\begin{array}{l}-4.975 * * * \\
(0.427)\end{array}$ & $\begin{array}{l}-4.717 * * * \\
(0.434)\end{array}$ & $\begin{array}{l}-5.346^{* * * *} \\
(0.513)\end{array}$ & $\begin{array}{l}-4.201 * * * \\
(0.398)\end{array}$ & $\begin{array}{l}-4.882^{* * *} \\
(0.483)\end{array}$ \\
\hline AIC & 264.3 & 212.6 & 210.7 & 185.8 & 291.1 & 203 \\
\hline Observations & 190 & 159 & 150 & 128 & 187 & 138 \\
\hline Adjusted $\mathrm{R}^{2}$ & 0.746 & 0.756 & 0.764 & 0.751 & 0.707 & 0.730 \\
\hline F Statistic & $93.356^{* * *}$ & $70.955^{* * *}$ & $81.186^{* * *}$ & $55.825 * * *$ & $75.924 * * *$ & $53.921 * * *$ \\
\hline
\end{tabular}

$* p<0.1 ; * * p<0.05 ; * * * p<0.01$

and social unrest, all transition countries are excluded from our second sample, namely no transtion countries. Sample year 2010 is restricted to 2010, the year in which we have original data on religious affiliations.

The first OLS estimate of a sample includes the political variables, religious diversity, and all controls, except tax revenue in percentage of GDP. These are added separately, since the inclusion of tax revenue results in a substantial and uneven loss of complete observations. The regression results are reported in Table $4 .^{9}$ The pairwise correlation matrix for all explanatory variables of the all countries sample is presented in Table 11 in "Appendix 2".

All specifications show that democratic leadership is associated with a higher average delivery quality than autocracies. However, delivery quality is not significantly higher or lower in theocratic than in autocratic regimes, as $\beta_{2}$ is not different from zero at the 95\%-level in all estimates. Both results confirm Hypothesis 1 . As

\footnotetext{
${ }^{9}$ All estimates are computed with the $1 \mathrm{~m}$-function of R version 3.5.3 (R Core Team 2019). Reported standard errors are rendered heteroskedasticity-robust by using the starprep-function of the estimatrpackage (Blair et al. 2018). The results are transferred to the stargazer-function of the stargazer-package (Hlavac 2018) in order to create Latex-formatted regression tables.
} 
expected, GDP per capita is associated with higher delivery quality. Surprisingly, natural resources rents in percentage of GDP are associated with lower levels of delivery quality, whereas higher religious diversity is associated with higher delivery quality in all specifications.

To deal with endogeneity concerns, we estimate a 2SLS model which we present in Table 12 in "Appendix 1". Instead of analysing the effect of religious requirements in general, we restrict our analysis to the association of muslim leadership with delivery quality. We create the dummy variable muslim theocracy as an indicator for autocratic countries in which heads of state are required to be muslim. Other autocracy is a dummy for autocratic countries without this requirement. Following Gouda and Gutmann (2019), we use the logarithm of the distance from Mecca as an instrument for muslim theocracy. The test for weak instruments is rejected, but the $\mathrm{Wu}-$ Hausman test suggests that there is no endogeneity, so that we retain the original OLS specifications.

\subsection{Religious diversity, quality of public goods and services, and political regime}

Next, we test whether the association of religious diversity with the quality of public goods and services depends on the political system, by adding interactions of religious diversity with regime dummies:

$$
\begin{aligned}
\text { delivery quality }_{i}= & \alpha+\beta_{1} \cdot \text { democratic }_{i}+\beta_{2} \cdot \text { theocratic }_{i} \\
& +\beta_{3} \cdot \text { religious diversity }_{i} \\
& +\beta_{4} \cdot \text { religious diversity }_{i} \cdot \text { democratic }_{i} \\
& +\beta_{5} \cdot \text { religious diversity }_{i} \cdot \text { theocratic }_{i} \\
& + \text { controls }_{i}+e_{i}
\end{aligned}
$$

The specification and computation of the results is carried out in the same way as above. The reference political system is autocratic again. Hence, $\beta_{3}$ captures the association of religious diversity with delivery quality in autocracies, whereas $\beta_{3}+\beta_{4}$ measures the association in democracies, and $\beta_{3}+\beta_{5}$ in theocracies. The regression results are reported in Table 5 . All specifications show that the positive association of religious diversity with delivery quality is restricted to democratic regimes, since $\beta_{3}+\beta_{4}>0$ in all cases. However, we cannot confirm Hypothesis 2 , which proposes a positive link between religious diversity and public goods and service quality in democratic and autocratic regimes, as $\beta_{3}=0$ cannot be rejected. As expected, religious diversity is not associated with delivery quality in theocratic regimes.

\subsection{Robustness tests}

\subsubsection{Differentiation within political regime types}

So far, we have classified countries as either theocratic, autocratic, or democratic, ignoring the fact that there might be political differences within these categories, or 
Table 5 Delivery quality, political regime and religious diversity: OLS estimates with political-religious interaction effects

\begin{tabular}{|c|c|c|c|c|c|c|}
\hline & \multicolumn{6}{|c|}{ Dependent variable: delivery quality } \\
\hline & \multicolumn{2}{|l|}{ All countries } & \multicolumn{4}{|l|}{ Sample } \\
\hline & & & \multicolumn{2}{|c|}{ No transition countries } & \multicolumn{2}{|l|}{ Year 2010} \\
\hline Democratic & $\begin{array}{l}0.146 \\
(0.138)\end{array}$ & $\begin{array}{l}0.124 \\
(0.135)\end{array}$ & $\begin{array}{l}0.279 \\
(0.173)\end{array}$ & $\begin{array}{l}0.209 \\
(0.187)\end{array}$ & $\begin{array}{l}0.091 \\
(0.148)\end{array}$ & $\begin{array}{l}0.192 \\
(0.172)\end{array}$ \\
\hline Theocratic & $\begin{array}{l}0.099 \\
(0.167)\end{array}$ & $\begin{array}{l}-0.050 \\
(0.176)\end{array}$ & $\begin{array}{l}0.077 \\
(0.190)\end{array}$ & $\begin{array}{l}-0.026 \\
(0.228)\end{array}$ & $\begin{array}{l}0.087 \\
(0.209)\end{array}$ & $\begin{array}{l}0.072 \\
(0.227)\end{array}$ \\
\hline Religious diversity & $\begin{array}{l}0.038 \\
(0.026)\end{array}$ & $\begin{array}{l}0.033 \\
(0.029)\end{array}$ & $\begin{array}{l}0.040 \\
(0.030)\end{array}$ & $\begin{array}{l}0.042 \\
(0.033)\end{array}$ & $\begin{array}{l}0.032 \\
(0.028)\end{array}$ & $\begin{array}{l}0.039 \\
(0.036)\end{array}$ \\
\hline $\begin{array}{l}\text { Religious diversity } \times \\
\text { Democratic }\end{array}$ & $\begin{array}{l}0.042 \\
(0.034)\end{array}$ & $\begin{array}{l}0.047 \\
(0.036)\end{array}$ & $\begin{array}{l}0.033 \\
(0.038)\end{array}$ & $\begin{array}{l}0.028 \\
(0.041)\end{array}$ & $\begin{array}{l}0.071 * \\
(0.036)\end{array}$ & $\begin{array}{l}0.061 \\
(0.042)\end{array}$ \\
\hline $\begin{array}{l}\text { Religious diversity } \times \\
\text { Theocratic }\end{array}$ & $\begin{array}{l}-0.033 \\
(0.062)\end{array}$ & $\begin{array}{l}-0.019 \\
(0.064)\end{array}$ & $\begin{array}{l}-0.019 \\
(0.067)\end{array}$ & $\begin{array}{l}-0.025 \\
(0.071)\end{array}$ & $\begin{array}{l}-0.006 \\
(0.077)\end{array}$ & $\begin{array}{l}-0.021 \\
(0.085)\end{array}$ \\
\hline Log GDP per capita & $\begin{array}{l}0.514 * * * \\
(0.033)\end{array}$ & $\begin{array}{l}0.499 * * * \\
(0.037)\end{array}$ & $\begin{array}{l}0.531 * * * \\
(0.039)\end{array}$ & $\begin{array}{l}0.525 * * * \\
(0.046)\end{array}$ & $\begin{array}{l}0.506 * * * \\
(0.037)\end{array}$ & $\begin{array}{l}0.509 * * * \\
(0.045)\end{array}$ \\
\hline Log population & $\begin{array}{l}-0.017 \\
(0.016)\end{array}$ & $\begin{array}{l}0.008 \\
(0.019)\end{array}$ & $\begin{array}{l}-0.001 \\
(0.019)\end{array}$ & $\begin{array}{l}0.016 \\
(0.023)\end{array}$ & $\begin{array}{l}-0.029 * \\
(0.017)\end{array}$ & $\begin{array}{l}-0.004 \\
(0.020)\end{array}$ \\
\hline Natural resources & $\begin{array}{l}-0.025^{* * *} \\
(0.003)\end{array}$ & $\begin{array}{l}-0.019 * * * \\
(0.004)\end{array}$ & $\begin{array}{l}-0.025^{* * *} \\
(0.004)\end{array}$ & $\begin{array}{l}-0.020 * * * \\
(0.004)\end{array}$ & $\begin{array}{l}-0.022^{* * *} \\
(0.003)\end{array}$ & $\begin{array}{l}-0.017 * * * \\
(0.004)\end{array}$ \\
\hline Tax revenue & & $\begin{array}{l}0.021 * * * \\
(0.006)\end{array}$ & & $\begin{array}{l}0.021 * * * \\
(0.007)\end{array}$ & & $\begin{array}{l}0.016 * * \\
(0.007)\end{array}$ \\
\hline Constant & $\begin{array}{l}-4.520 * * * \\
(0.407)\end{array}$ & $\begin{array}{l}-5.123^{* * * *} \\
(0.447)\end{array}$ & $\begin{array}{l}-4.984 * * * \\
(0.489)\end{array}$ & $\begin{array}{l}-5.525^{* * *} \\
(0.579)\end{array}$ & $\begin{array}{l}-4.303^{* * *} \\
(0.428)\end{array}$ & $\begin{array}{l}-5.057 * * * \\
(0.509)\end{array}$ \\
\hline \multicolumn{7}{|c|}{ Association of religious diversity with delivery quality in democratic and theocratic regimes } \\
\hline $\begin{array}{l}\text { Democratic } \text { Religious } \\
\text { diversity }+ \text { Religious } \\
\text { diversity } \times \text { Democratic }\end{array}$ & $\begin{array}{l}0.080 * * * \\
(0.022)\end{array}$ & $\begin{array}{l}0.080 * * * \\
(0.022)\end{array}$ & $\begin{array}{l}0.074 * * * \\
(0.025)\end{array}$ & $\begin{array}{l}0.070 * * * \\
(0.026)\end{array}$ & $\begin{array}{l}0.103 * * * \\
(0.023)\end{array}$ & $\begin{array}{l}0.100 * * * \\
(0.025)\end{array}$ \\
\hline $\begin{array}{l}\text { Theocratic Religious } \\
\text { diversity }+ \text { Religious } \\
\text { diversity } \times \text { Theocratic }\end{array}$ & $\begin{array}{l}0.005 \\
(0.056)\end{array}$ & $\begin{array}{l}0.014 \\
(0.056)\end{array}$ & $\begin{array}{l}0.022 \\
(0.059)\end{array}$ & $\begin{array}{l}0.017 \\
(0.061)\end{array}$ & $\begin{array}{l}0.026 \\
(0.070)\end{array}$ & $\begin{array}{l}0.018 \\
(0.078)\end{array}$ \\
\hline $\mathrm{AIC}$ & 265.8 & 214.3 & 213.6 & 189.1 & 290.8 & 204.3 \\
\hline Observations & 190 & 159 & 150 & 128 & 187 & 138 \\
\hline Adjusted $\mathrm{R}^{2}$ & 0.746 & 0.756 & 0.762 & 0.749 & 0.711 & 0.731 \\
\hline F Statistic & $70.446^{* * * *}$ & $55.464 * * *$ & $60.598 * * *$ & $43.018 * * *$ & $58.134 * * *$ & $42.421 * * *$ \\
\hline
\end{tabular}

$* p<0.1 ; * * p<0.05 ; * * * p<0.01$

changes over time that may affect the provision of public goods and services. Moreover, we assumed that religious requirements for heads of state are not linked to the quality of public goods and services in democracies. To allow for a more detailed political differentiation within regimes, we use the polity2 score of the Polity IV 
database. ${ }^{10}$ The polity 2 score is a 21-point scale ranging from -10 (high autocracy) to +10 (high democracy). Since the association of religious requirements and religious diversity with the quality of public goods and services is likely to depend on the political institutions captured by the polity 2 score, we specify the following model:

$$
\begin{aligned}
& \text { delivery quality }_{i, t}=\alpha+\beta_{1} \cdot \text { polity }_{i, t}+\beta_{2} \cdot \text { religious leader }_{i} \\
& +\beta_{3} \cdot \text { polity }_{i, t} \cdot \text { religious leader }_{i} \\
& +\beta_{4} \cdot \text { religious diversity } \\
& +\beta_{5} \cdot \text { polity }_{i, t} \cdot \text { religious diversity }_{i} \\
& +\beta_{6} \cdot \text { polity }_{i, t} \cdot \text { religious diversity }_{i} \cdot \text { religious leader }_{i} \\
& + \text { controls }_{i, t}+e_{i, t}
\end{aligned}
$$

We estimate the association of country i's polity 2 score with deliveryquality at time $t$. Religious leader and religious diversity are interacted with the polity 2 score separately and simultaneously, in order to estimate a conditional association with delivery quality. Since the use of the polity 2 score as a measure of political regimes results in far greater regime variation, we now use annual data in the first two specifications and report cluster-robust standard errors at the country level in these cases. Estimations three and four use country-averages. The computation of results is carried out as before, and the regression results are reported in Table 6.

It is noteworthy that we do not use country fixed effects in our estimations. Since religious requirements and the religious affiliation do not vary over time in our data, the application of fixed effects would use up almost all variance in the data. A regression with fixed effects and a constant (not shown here) results in an adjusted R-squared value of about 0.97 .

Figure 1 depicts the marginal effects of religious requirements on delivery quality, conditional on the polity 2 score. There is a statistically significant positive association between religious requirements and delivery quality in the polity 2 range from -10 to -2 , and a negative marginal effect in the range from 6 to 10 in the first specification. The marginal effect of religious diversity on delivery quality is positive for polity 2 values above -4 in countries without a religious leader, as Fig. 2 shows. There are no significant marginal effects of religious diversity in countries with religious leaders in the polity 2 range from -10 to -5 , and from 4 to 10 .

\subsubsection{Alternative operationalization of theocracy}

As a second robustness check, we apply a different operationalization of theocracy, using an alternative source dealing with secularization, namely the "Religion and State Project Round 3 (RAS3)", provided by Fox (2017). The RAS3 includes the

\footnotetext{
10 See Cheibub et al. (2010) for an analysis of different indices for dictatorship and democracy. One obvious disadvantage of using the more differentiated polity 2 score, compared to the Bjørnskov and Rode (2020) data, is the additional missing regime data for 639 observations.
} 
Table 6 Delivery quality, political regime and religious diversity: OLS estimates with differentiated political regimes

\begin{tabular}{|c|c|c|c|c|}
\hline & \multicolumn{4}{|c|}{ Dependent variable: delivery quality } \\
\hline & \multicolumn{4}{|l|}{ Sample } \\
\hline & \multicolumn{2}{|l|}{ Annual data } & \multicolumn{2}{|c|}{ Country-averages } \\
\hline \multirow[t]{2}{*}{ Polity2 } & $0.026^{* *}$ & $0.041^{* * *}$ & $0.025^{*}$ & $0.028^{*}$ \\
\hline & $(0.011)$ & $(0.014)$ & $(0.014)$ & $(0.015)$ \\
\hline \multirow[t]{2}{*}{ Religious leader } & 0.094 & 0.143 & 0.066 & -0.016 \\
\hline & $(0.096)$ & $(0.125)$ & $(0.103)$ & $(0.127)$ \\
\hline \multirow[t]{2}{*}{ Polity $2 \times$ Religious leader } & $-0.044 * *$ & $-0.057 * *$ & $-0.050 *$ & $-0.057 * *$ \\
\hline & $(0.019)$ & $(0.024)$ & $(0.026)$ & $(0.026)$ \\
\hline \multirow[t]{2}{*}{ Religious diversity } & $0.064 * * *$ & $0.087 * * *$ & $0.061 * * *$ & $0.073 * * *$ \\
\hline & $(0.018)$ & $(0.022)$ & $(0.019)$ & $(0.020)$ \\
\hline \multirow[t]{2}{*}{ Polity $2 \times$ Religious diversity } & $0.004^{*}$ & 0.001 & 0.005 & 0.003 \\
\hline & $(0.003)$ & $(0.003)$ & $(0.003)$ & $(0.003)$ \\
\hline \multirow{2}{*}{$\begin{array}{l}\text { Polity } 2 \times \text { Religious leader } \times \\
\text { Religious diversity }\end{array}$} & -0.005 & -0.005 & -0.005 & -0.002 \\
\hline & $(0.007)$ & $(0.009)$ & $(0.009)$ & $(0.009)$ \\
\hline \multirow[t]{2}{*}{ Log GDP per capita } & $0.468^{* * * *}$ & $0.507 * * *$ & $0.477 * * *$ & $0.477 * * *$ \\
\hline & $(0.033)$ & $(0.038)$ & $(0.036)$ & $(0.037)$ \\
\hline \multirow[t]{2}{*}{ Log population } & -0.017 & -0.002 & -0.011 & 0.008 \\
\hline & $(0.021)$ & $(0.024)$ & $(0.021)$ & $(0.025)$ \\
\hline \multirow[t]{2}{*}{ Natural resources } & $-0.019 * * *$ & $-0.016^{* * * *}$ & $-0.022 * * *$ & $-0.018 * * *$ \\
\hline & $(0.002)$ & $(0.004)$ & $(0.004)$ & $(0.004)$ \\
\hline \multirow[t]{2}{*}{ Tax revenue } & & $0.014 * *$ & & $0.016^{* *}$ \\
\hline & & $(0.006)$ & & $(0.007)$ \\
\hline \multirow[t]{2}{*}{ Constant } & $-4.244 * * *$ & $-5.180 * * *$ & $-4.401 * * *$ & $-4.996 * * *$ \\
\hline & $(0.465)$ & $(0.541)$ & $(0.480)$ & $(0.567)$ \\
\hline Countries & 160 & 137 & 160 & 137 \\
\hline AIC & 4015.5 & 2538.5 & 216.8 & 177.9 \\
\hline Observations & 2,926 & 2,011 & 160 & 137 \\
\hline Adjusted $\mathrm{R}^{2}$ & 0.750 & 0.779 & 0.770 & 0.788 \\
\hline F Statistic & $976.416^{* * *}$ & $711.074 * * *$ & $60.155^{* * * *}$ & $51.624 * * *$ \\
\hline
\end{tabular}

$* p<0.1 ; * * p<0.05 ; * * * p<0.01$

variable Official Support, which describes the formal relationship between religion and state for the years from 1990 to 2014. This relationship is coded on a 14-point scale from 0 to 13 , with high values indicating a strong relationship and the absence of secularization, either by law or consistent government practice. Countries with an official religion have a score of 10 points or higher. In these countries, the "state actively supports religion but the religion is not mandatory and the state does not dominate the official religion's institutions" (10 points; Codebook in Fox 2017), "supports a religion and substantially controls its institutions but has a positive attitude toward this religion" (11 points; Codebook in Fox 2017), religion 


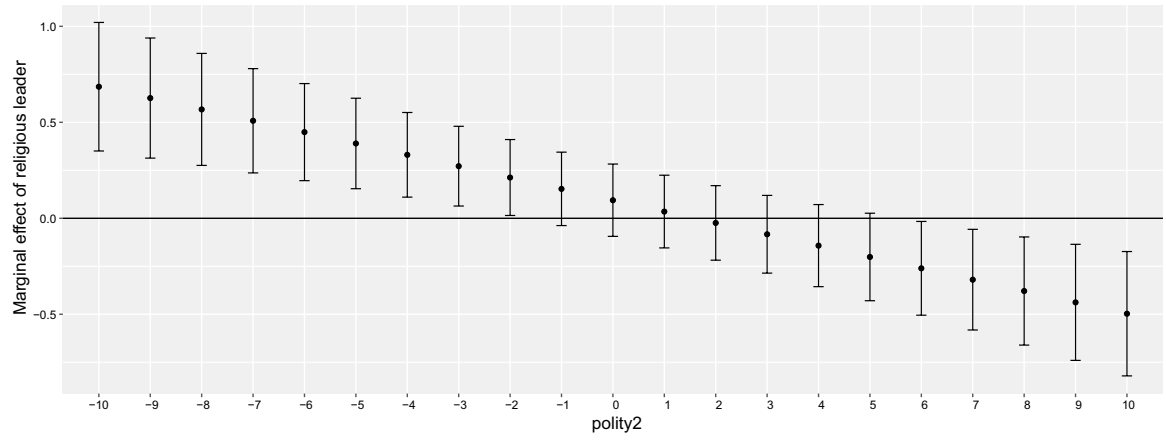

Fig. 1 Marginal effects of religious leaders on delivery quality according to the polity2 score. Effects refer to the first specification in Table 6 with $95 \%$ confidence intervals

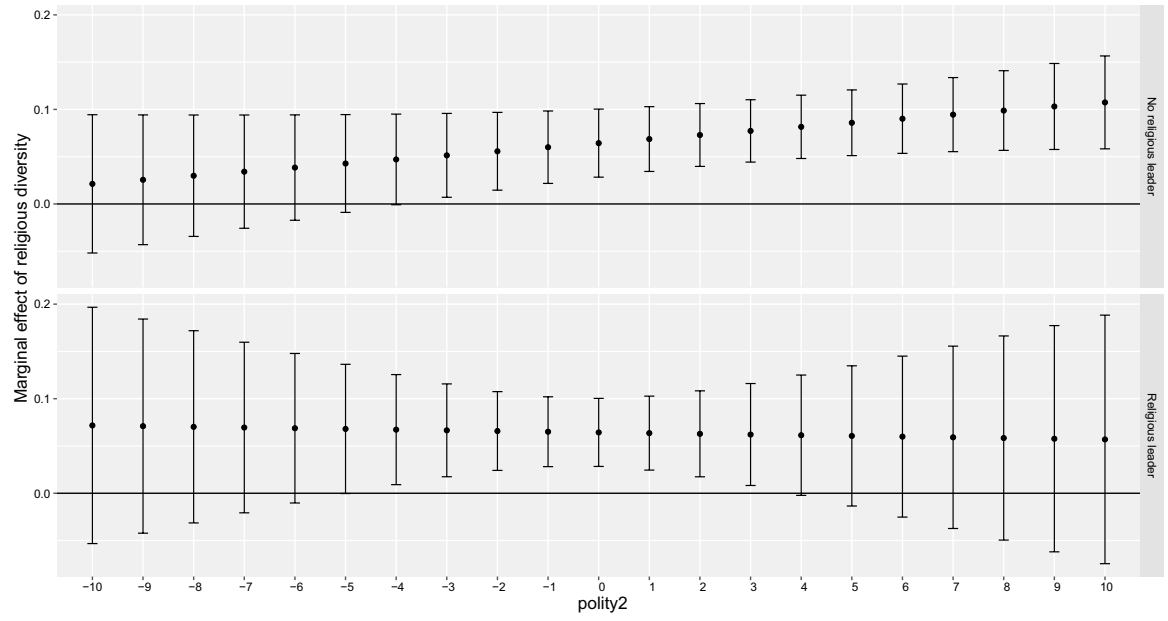

Fig. 2 Marginal effects of religious diversity on delivery quality according to the polity2 score for countries without and with a religious leader. Effects refer to the first specification in Table 6 with $95 \%$ confidence intervals

is "mandatory for members of the official religion" (12 points; Codebook in Fox 2017), or religion is "mandatory for all" (13 points; Codebook in Fox 2017). We combine this alternative criterion for the absence of secularization with the regimedataset provided by Bjørnskov and Rode (2020). Now, countries which are classified as non-democracy by Bjørnskov and Rode (2020), are coded as theocratic (RAS3) if the Official Support variable has a value of 10 points or higher. All other countries are classified as either autocratic or democratic according to the Bjørnskov and Rode (2020) regime-data. The subset of countries classified as theocratic by using different operationalizations, is presented in Table 7. We use the same specification as in the basic cross-country model in Sect. 5.1. Regression results using this alternative operationalization are summarized in Table 8. Again, all specifications show 


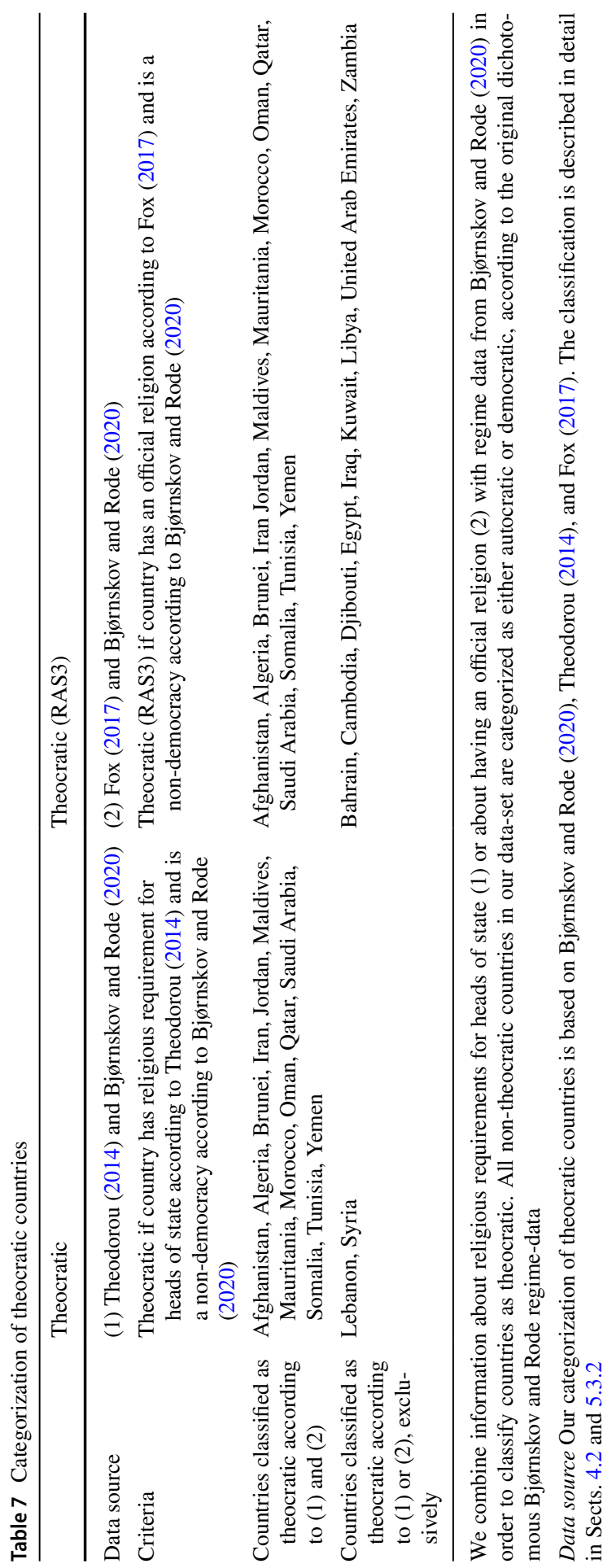


Table 8 Delivery quality, political regime and religious diversity: cross-country OLS estimates with alternative operationalization of theocracy according to Religion and State data (RAS3; Fox 2017)

\begin{tabular}{|c|c|c|c|c|c|c|}
\hline & \multicolumn{6}{|c|}{ Dependent variable: delivery quality } \\
\hline & \multicolumn{2}{|c|}{ All countries } & \multicolumn{4}{|l|}{ Sample } \\
\hline & & & \multicolumn{2}{|c|}{ No transition countries } & \multicolumn{2}{|l|}{ Year 2010} \\
\hline Democratic & $\begin{array}{l}0.305 * * * \\
(0.095)\end{array}$ & $\begin{array}{l}0.339 * * * \\
(0.103)\end{array}$ & $\begin{array}{l}0.412 * * * \\
(0.120)\end{array}$ & $\begin{array}{l}0.371 * * * \\
(0.139)\end{array}$ & $\begin{array}{l}0.357 * * * \\
(0.106)\end{array}$ & $\begin{array}{l}0.512 * * * \\
(0.138)\end{array}$ \\
\hline Theocratic (RAS3) & $\begin{array}{l}0.117 \\
(0.118)\end{array}$ & $\begin{array}{l}0.175 \\
(0.142)\end{array}$ & $\begin{array}{l}0.084 \\
(0.129)\end{array}$ & $\begin{array}{l}0.156 \\
(0.169)\end{array}$ & $\begin{array}{l}0.188 \\
(0.139)\end{array}$ & $\begin{array}{l}0.355^{* *} \\
(0.167)\end{array}$ \\
\hline Religious diversity & $\begin{array}{l}0.060 * * * \\
(0.016)\end{array}$ & $\begin{array}{l}0.066 * * * \\
(0.017)\end{array}$ & $\begin{array}{l}0.057 * * * \\
(0.019)\end{array}$ & $\begin{array}{l}0.063 * * * \\
(0.021)\end{array}$ & $\begin{array}{l}0.071 * * * \\
(0.018)\end{array}$ & $\begin{array}{l}0.084 * * * \\
(0.021)\end{array}$ \\
\hline Log GDP per capita & $\begin{array}{l}0.508 * * * \\
(0.033)\end{array}$ & $\begin{array}{l}0.481 * * * \\
(0.038)\end{array}$ & $\begin{array}{l}0.527 * * * \\
(0.039)\end{array}$ & $\begin{array}{l}0.507 * * * \\
(0.047)\end{array}$ & $\begin{array}{l}0.500 * * * \\
(0.036)\end{array}$ & $\begin{array}{l}0.488 * * * \\
(0.043)\end{array}$ \\
\hline Log population & $\begin{array}{l}-0.015 \\
(0.015)\end{array}$ & $\begin{array}{l}0.010 \\
(0.018)\end{array}$ & $\begin{array}{l}0.003 \\
(0.018)\end{array}$ & $\begin{array}{l}0.020 \\
(0.022)\end{array}$ & $\begin{array}{l}-0.026 \\
(0.016)\end{array}$ & $\begin{array}{l}-0.001 \\
(0.020)\end{array}$ \\
\hline Natural resources & $\begin{array}{l}-0.026^{* * *} \\
(0.003)\end{array}$ & $\begin{array}{l}-0.019^{* * * *} \\
(0.003)\end{array}$ & $\begin{array}{l}-0.025^{* * * *} \\
(0.003)\end{array}$ & $\begin{array}{l}-0.021^{* * *} \\
(0.004)\end{array}$ & $\begin{array}{l}-0.022^{* * *} \\
(0.003)\end{array}$ & $\begin{array}{l}-0.017 * * * \\
(0.004)\end{array}$ \\
\hline Tax revenue & & $\begin{array}{l}0.024 * * * \\
(0.007)\end{array}$ & & $\begin{array}{l}0.023 * * * \\
(0.007)\end{array}$ & & $\begin{array}{l}0.021 * * \\
(0.008)\end{array}$ \\
\hline Constant & $\begin{array}{l}-4.597 * * * \\
(0.391)\end{array}$ & $\begin{array}{l}-5.194 * * * \\
(0.433)\end{array}$ & $\begin{array}{l}-5.094 * * * \\
(0.439)\end{array}$ & $\begin{array}{l}-5.582 * * * \\
(0.516)\end{array}$ & $\begin{array}{l}-4.464^{* * *} \\
(0.413)\end{array}$ & $\begin{array}{l}-5.258^{* * *} \\
(0.491)\end{array}$ \\
\hline AIC & 263.9 & 211.2 & 210.5 & 185.1 & 290.3 & 199 \\
\hline Observations & 190 & 159 & 150 & 128 & 187 & 138 \\
\hline Adjusted $\mathrm{R}^{2}$ & 0.746 & 0.758 & 0.764 & 0.753 & 0.709 & 0.738 \\
\hline F Statistic & $93.614 * * *$ & $71.725^{* * *}$ & $81.285^{* * *}$ & $56.224 * * *$ & $76.413 * * *$ & $56.084 * * *$ \\
\hline
\end{tabular}

$* p<0.1 ; * * p<0.05 ; * * * p<0.01$

that democratic leadership is associated with a higher average delivery quality than autocracies. Theocratic leadership is not associated with a different quality of public goods and services, compared to secular autocracies in all but one specification. In this specification, which uses data from 2010 and tax revenue as a control, delivery quality is significantly higher in theocratic compared to autocratic regimes. As Hypothesis 1 is confirmed in both cases, our results are robust to the application of an alternative operationalization of theocracy.

\subsubsection{Disaggregation of delivery quality}

The four underlying indicators of delivery quality, namely government effectiveness, regulatory quality, rule of law, and control of corruption, are closely related to the quality of public goods and services in various respects, and, as Table 9 shows, they are highly correlated. Nevertheless, creating a single composite index with equal weights might be questionable. We run separate regressions 
Table 9 Correlation matrix of delivery quality and its four underlying indices

Delivery quality Government Regulatory quality Rule of law Control of

\begin{tabular}{llllll}
\hline $\begin{array}{l}\text { Delivery quality } \\
\text { Government effective- } \\
\quad \text { ness }\end{array}$ & 0.978 & 1 & & & \\
Regulatory quality & 0.956 & 0.933 & 1 & & \\
Rule of law & 0.975 & 0.931 & 0.902 & 1 & \\
Control of corruption & 0.964 & 0.924 & 0.867 & 0.941 & 1 \\
\hline
\end{tabular}

Table 10 Delivery quality and its constituent indices, political regime and religious diversity: crosscountry OLS estimates

\begin{tabular}{|c|c|c|c|c|c|}
\hline & \multicolumn{5}{|c|}{ Dependent variable } \\
\hline & Delivery quality & $\begin{array}{l}\text { Government } \\
\text { effectiveness }\end{array}$ & Regulatory quality & Rule of law & $\begin{array}{l}\text { Control of } \\
\text { corruption }\end{array}$ \\
\hline Democratic & $\begin{array}{l}0.288 * * * \\
(0.087)\end{array}$ & $\begin{array}{l}0.232 * * * \\
(0.085)\end{array}$ & $\begin{array}{l}0.317 * * * \\
(0.095)\end{array}$ & $\begin{array}{l}0.326 * * * \\
(0.097)\end{array}$ & $\begin{array}{l}0.276^{* * * *} \\
(0.098)\end{array}$ \\
\hline Theocratic & $\begin{array}{l}0.086 \\
(0.136)\end{array}$ & $\begin{array}{l}0.111 \\
(0.125)\end{array}$ & $\begin{array}{l}0.101 \\
(0.158)\end{array}$ & $\begin{array}{l}0.083 \\
(0.150)\end{array}$ & $\begin{array}{l}0.050 \\
(0.159)\end{array}$ \\
\hline Religious diversity & $\begin{array}{l}0.057 * * * \\
(0.016)\end{array}$ & $\begin{array}{l}0.058 * * * \\
(0.016)\end{array}$ & $\begin{array}{l}0.054 * * * \\
(0.017)\end{array}$ & $\begin{array}{l}0.054 * * * \\
(0.017)\end{array}$ & $\begin{array}{l}0.064 * * * \\
(0.019)\end{array}$ \\
\hline $\begin{array}{l}\text { Log GDP per } \\
\text { capita }\end{array}$ & $\begin{array}{l}0.513 * * * \\
(0.031)\end{array}$ & $\begin{array}{l}0.559 * * * \\
(0.031)\end{array}$ & $\begin{array}{l}0.514 * * * \\
(0.031)\end{array}$ & $\begin{array}{l}0.487 * * * \\
(0.035)\end{array}$ & $\begin{array}{l}0.491 * * * \\
(0.038)\end{array}$ \\
\hline Log population & $\begin{array}{l}-0.014 \\
(0.015)\end{array}$ & $\begin{array}{l}0.019 \\
(0.015)\end{array}$ & $\begin{array}{l}0.026 \\
(0.018)\end{array}$ & $\begin{array}{l}-0.054 * * * \\
(0.017)\end{array}$ & $\begin{array}{l}-0.050^{* * *} \\
(0.018)\end{array}$ \\
\hline Natural resources & $\begin{array}{l}-0.025^{* * *} \\
(0.003)\end{array}$ & $\begin{array}{l}-0.026^{* * *} \\
(0.003)\end{array}$ & $\begin{array}{l}-0.026^{* * *} \\
(0.003)\end{array}$ & $\begin{array}{l}-0.025^{* * *} \\
(0.003)\end{array}$ & $\begin{array}{l}-0.023 * * * \\
(0.004)\end{array}$ \\
\hline Constant & $\begin{array}{l}-4.340^{* * *} \\
(0.385)\end{array}$ & $\begin{array}{l}-5.295^{* * *} \\
(0.372)\end{array}$ & $\begin{array}{l}-4.939 * * * \\
(0.410)\end{array}$ & $\begin{array}{l}-3.485^{* * *} \\
(0.445)\end{array}$ & $\begin{array}{l}-3.641 * * * \\
(0.472)\end{array}$ \\
\hline AIC & 264.3 & 251.7 & 272.3 & 304.8 & 337.1 \\
\hline Observations & 190 & 190 & 190 & 190 & 190 \\
\hline Adjusted $\mathrm{R}^{2}$ & 0.746 & 0.773 & 0.740 & 0.701 & 0.655 \\
\hline F Statistic & $93.356 * * *$ & $108.150 * * *$ & $90.435 * * *$ & $74.956 * * *$ & $60.908 * * *$ \\
\hline
\end{tabular}

$* p<0.1 ; * * p<0.05 ; * * * p<0.01$

for all four underlying variables in order to determine whether one of the indicators drives the results of our empirical analysis. We use the all countries sample and estimate our preferred specification of the basic cross-country model. This specification includes all explanatory variables and controls, but excludes tax revenue, due to data unavailability.

Table 10 shows that our results are robust to the disaggregation of our composite indicator delivery quality. 


\section{Conclusion}

In this paper, we analyze the influence of religion on the quality of public goods and services. We determine two hypothesis, using a modification of the Buchanan-Brennan Leviathan framework. Firstly, we conjecture that religious leaders provide a lower quality of public goods and services than democratic leaders, due to a lack of accountability of politicians in theocratic regimes. Secondly, we hypothesize that religious diversity increases the quality of public goods and services in autocratic regimes and democracies. As religious goods are provided privately in these regimes, they may substitute public goods provided by the state and thus lower the perceived quality of the latter. Due to economies of scale, the private provision of religious goods is lower if religious diversity is higher.

We test the theoretical differences in the quality of public goods and services, employing the so-called delivery quality index as a proxy-variable. We demonstrate that political systems matter for the provision of public goods and services. All specifications show that religious and autocratic leadership may be associated with a lower average delivery quality than democracies. Delivery quality is not significantly lower in theocratic regimes than in autocratic regimes. These results are robust to the disaggregation of the composite delivery quality indicator. However, if we allow for a more detailed political differentiation, there is a statistically significant positive association between religious leadership and delivery quality in strict autocracies. A higher level of religious diversity is linked to higher delivery quality in democratic countries and non-strict autocracies without religious leaders.

Although we find significant differences between the provision of public goods and services in different political regimes, our analysis does not necessarily imply that switching from one political system to another will increase (or decrease) the quality of public goods and services, and thereby the wellbeing of citizens. Our analysis is limited to the comparison of different political regimes, but does not describe the effects of regime transitions within a country. The analysis of regime transitions and its implications for the provision of public goods is a topic for further research. The same is true for changes in religious diversity within countries.

Acknowledgements We thank Antonis Adam and the participants at the 3rd International Conference on the Political Economy of Democracy and Dictatorship in Münster for their helpful comments. Moreover, we are grateful for valuable comments from two anonymous referees and by the journals's co-editor, Amihai Glazer. We also thank Brian Bloch for his English editing. Nevertheless, the usual disclaimer applies.

Funding Open Access funding provided by Projekt DEAL.

Code availability $\mathrm{R}$-code is available upon request.

\section{Compliance with ethical standards}

Conflict of interest The authors declare that they have no conflict of interest. 
Open Access This article is licensed under a Creative Commons Attribution 4.0 International License, which permits use, sharing, adaptation, distribution and reproduction in any medium or format, as long as you give appropriate credit to the original author(s) and the source, provide a link to the Creative Commons licence, and indicate if changes were made. The images or other third party material in this article are included in the article's Creative Commons licence, unless indicated otherwise in a credit line to the material. If material is not included in the article's Creative Commons licence and your intended use is not permitted by statutory regulation or exceeds the permitted use, you will need to obtain permission directly from the copyright holder. To view a copy of this licence, visit http://creativecommons.org/licen ses/by/4.0/.

\section{Appendix 1: Tables}

See Tables 11 and 12. 


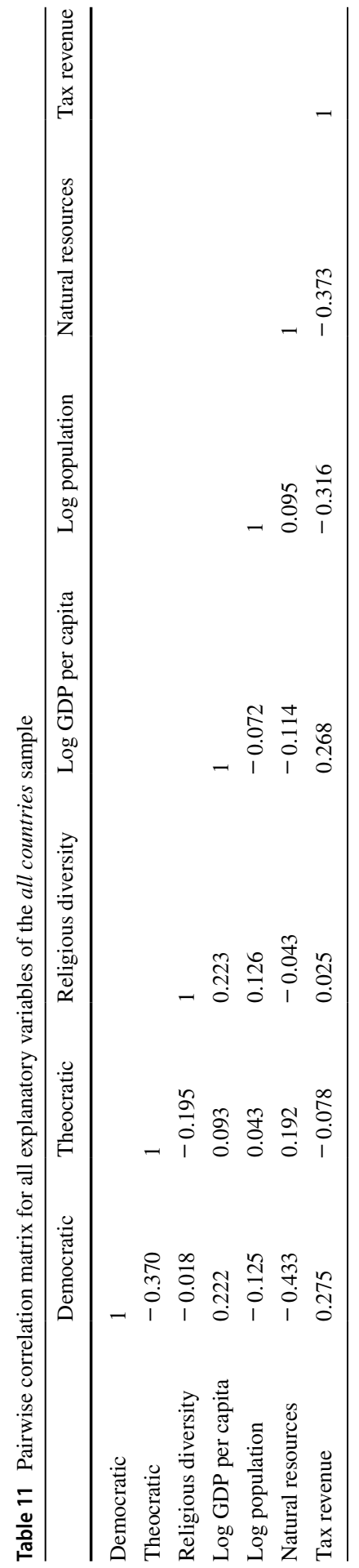


Table 12 Delivery quality, political regime and religious diversity: 2SLS cross-section regression

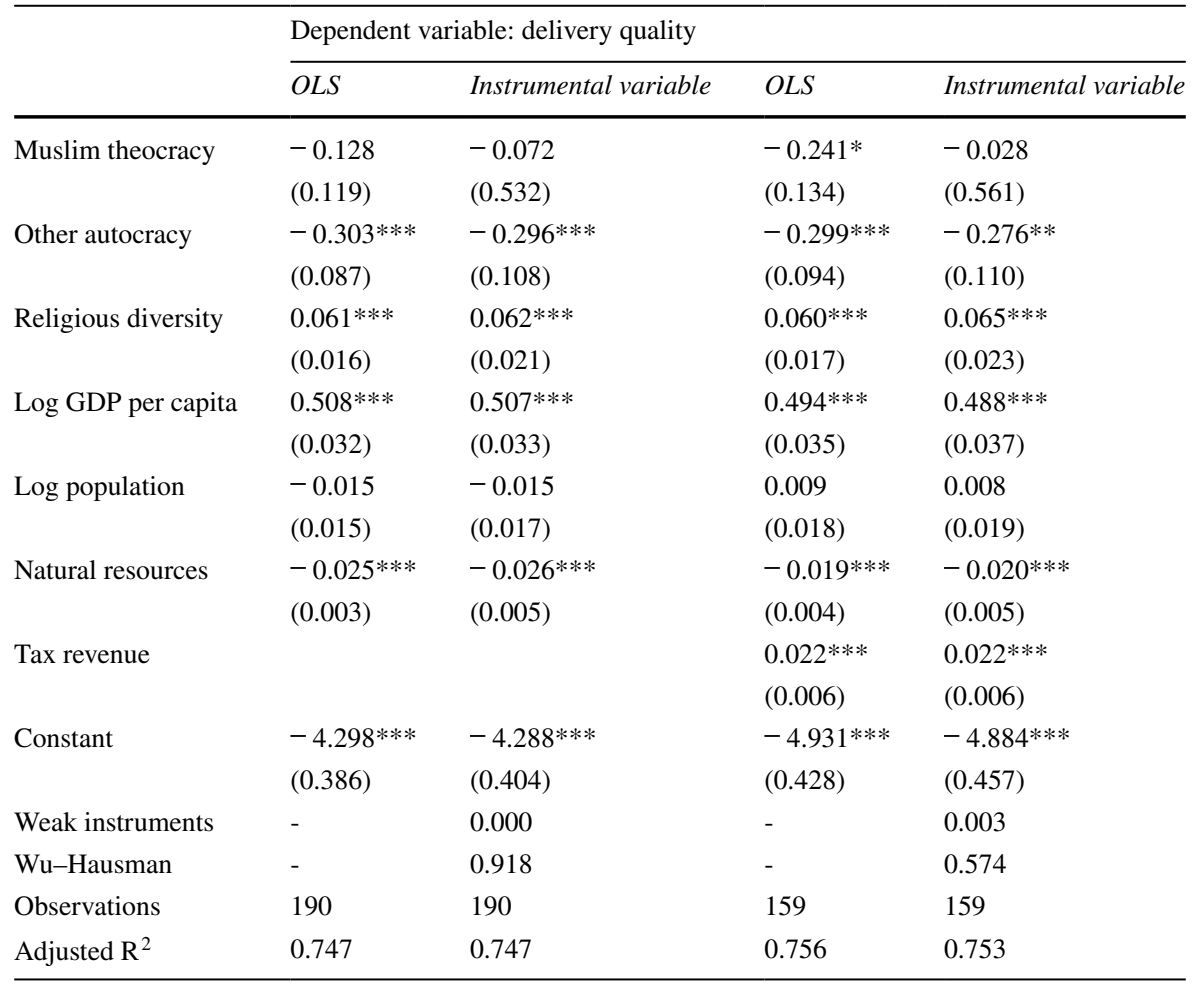

The variable 'muslim theocracy' is instrumented by the logarithm of the distance to Mecca $* p<0.1 ; * * p<0.05 ; * * * p<0.01$

\section{Appendix 2: Theoretical model}

In this section, we depict, with a very simple model, the differences between the determination of public goods and services in a theocratic society, an authoritarian society and a democratic society. ${ }^{11}$ In the text below, the following variables are used:

- $G^{i}$ : quality-adjusted level of public goods and services provided by group $i=R, A, D$ with $R$ as religious leaders, $A$ as members of the so-called winning coalition (Bueno de Mesquita et al. 2003) in an authoritarian state and $D$ as the political leadership in a democracy,

- $x^{i}$ : tax-financed private consumption ${ }^{12}$ of leadership group $i=R, A, D$,

\footnotetext{
${ }^{11}$ See Deacon (2009) for an elaborated model of public goods provision under different political regimes, but without religious leadership.

12 These private goods are referred to as rents by Plümper and Martin (2003), as well as Hausken et al. (2004).
} 
- $0<r, a, \delta<1$ : the share of political leaders in theocratic, autocratic and democratic regimes, in \% of the population (Engineer 1989, 1990 emphasizes the importance of the number of rulers in Leviathan regime models),

- $v$ : average citizen's wealth,

- $\rho^{i}$ : religious goods under regime $i$,

- $u\left(v, G^{i}, \rho^{i}\right)$ : average citizen's utility from wealth, public goods and services, and religious goods,

- $U^{i}\left(x^{i}, G^{i}\right)$ : objective function of the leadership in regime $i=R, A, D$,

- $T^{i}$ : tax revenue in regime $i=R, A, D$.

\section{Theocracy}

In a theocratic society, the religious leaders decide on the level and quality of religious goods, $\rho$. In addition, they also determine the quality-adjusted level of public goods and services, $G^{R}$. However, religious leaders appropriate part of the tax revenue $T^{R}$ for private consumption, $x^{R}$. In addition, they consider in these decisions, religious and public goods in so far as they are suitable for legitimizing their leadership. The legitimization effect is captured by the factor $0<\mu^{R} \leq 1$. Accordingly, the objective function of the religious leadership is given by:

$$
U^{R}\left(x^{R}, \rho^{R}\right)=x^{R}+\mu^{R}\left(\rho^{R}+G^{R}\right) .
$$

According to this function, religious leaders are interested in their own tax-financed private consumption, $x^{R}$, as well as in the provision of religious goods, $\rho^{R}$, and public goods and services, $G^{R}$, if such provision supports the legitimization of the religious leadership. Note that the religious leaders are interested in the state provision of religious goods. This is an important difference between a theocratic regime and autocratic or democratic regimes. Moreover, it is assumed that the state providing religious goods simultaneously with public goods creates an advantage, because overlaps between public and religious goods (that are also at least partially public goods) can be avoided.

The utility function of an average citizen in a theocracy is assumed as:

$$
u\left(v, G^{R}, \rho^{R}\right)=v+\alpha \ln \rho^{R}+\beta \ln G^{R} .
$$

This utility function implies that the cross-derivatives of the utility function are zero. The coefficients $\alpha>0$ and $\beta>0$ represent the average preference for religious and public goods of an average citizen, respectively (Coşgel and Miceli 2009).

Applying a Leviathan model of political leadership (Brennan and Buchanan 1980; Wintrobe 1998), as adapted by Coşgel and Miceli (2009), taxes on wealth are set to leave citizens with a reservation utility level of $u \geq \bar{u}$. From an average citizen's viewpoint, the tax function reads (Coşgel and Miceli 2009, p. 406):

$$
T^{R}=v+\alpha \ln \rho^{R}+\beta \ln G^{R}-\bar{u} .
$$

The leaderships budget constraint (per average citizen) is given by: 


$$
T^{R}=r x^{R}+G^{R}+c \rho^{R},
$$

with $r$ as the population share of religious leaders and $c$ the constant unit cost of religious goods. The price of public goods (the numeraire) is set equal to unity. Setting these tax functions equal gives the tax-financed private consumption of the religious leaders:

$$
x^{R}=\frac{1}{r}\left(v+\alpha \ln \rho^{R}-c \rho^{R}+\beta \ln G^{R}-G^{R}-\bar{u}\right) .
$$

Furthermore, it is assumed that the religious leaders are a homogeneous group with identical preferences. Inserting the above expression for $x^{R}$ into the religious leaders' objective function, the (unconstrained) maximization program of religious leaders is given by:

$$
\max _{G^{R}, \rho^{R}} \frac{1}{r}\left(v+\alpha \ln \rho^{R}-c \rho^{R}+\beta \ln G^{R}-G^{R}-\bar{u}\right)+\mu^{R}\left(\rho^{R}+G^{R}\right) .
$$

The first-order conditions for this program are:

$$
\begin{aligned}
& \frac{1}{r}\left(\frac{\beta}{G^{R}}-1\right)+\mu^{R}=0 \Longrightarrow G^{R}=\frac{\beta}{1-r \mu^{R}}, \\
& \frac{1}{r}\left(\frac{\alpha}{\rho^{R}}-c\right)+\mu^{R}=0 \Longrightarrow \rho^{R}=\frac{\alpha}{c-r \mu^{R}} .
\end{aligned}
$$

Note that the size of the religious leadership is restricted, since the level of both the religious and the public goods must be larger than zero. Therefore: $r<\min \left(\frac{1}{\mu^{R}}, \frac{c}{\mu^{R}}\right)$.

The optimal levels of public goods and services and religious goods in Eqs. (10) and (11) contain the term $r \mu^{R}$. The larger this expression, the higher the respective goods levels. This effect results from the legitimization effect of both religious and public goods for the religious leadership. However, since both goods are financed by the same source, i.e. tax revenue, they compete with each other and with the private tax-financed consumption of the leaders. The above restriction on the number of religious leaders shows this effect. Given the legitimization effect of religious and public goods and services, the population share of leadership, $r$, is constrained by the required volume of these goods.

\section{Autocracy}

In an authoritarian society, the political leadership uses tax revenue to "buy" the loyalty of a subgroup of the population, whose support is necessary to stay in power, the so-called winning (autocratic) coalition, A (Bueno de Mesquita et al. 2003), whereby $a$ denotes the population share of the members of the winning coalition. Hence, autocratic regimes also finance part of their leadership's private 
consumption through taxes. Moreover, the provision of public goods is employed to legitimize the regime. The legitimization effect is measured by $0<\mu^{A} \leq 1$. In contrast to theocratic regimes, autocratic regimes do not provide religious goods. Unless the regime oppresses certain religions, religious goods are provided privately.

The average citizen in an autocratic (and in a democratic) regime with free choice of religion and competitive religious markets maximizes the following utility function:

$$
u(v, \rho, G)=v+\alpha \ln \rho+\beta \ln G-\phi \ln \rho G .
$$

In contrast to theocratic regimes, an overlap between religious and public goods may occur. This is anticipated; in the average citizen's utility function the utility loss due to the overlap effect is subtracted. The size of the effect is accounted for by $0<\phi<1$. The higher the value of $\phi$, the larger the overlap. Note that $(1-\phi)$ is interpreted here as a measure of religious diversity. This means that a higher value of $\phi$ implies higher levels of religious homogeneity (less religious diversity). The reason is that greater religious homogeneity generates a larger degree of overlap between public goods and religious goods that are also public goods (e.g., churches, mosques, temples, social support etc.). In contrast, a high degree of religious diversity substantially reduces the respective overlap. Put differently, different religions compete with one another with regard to specific religious goods. This may reduce the overlap insofar as very specific religious goods are provided that differ to a larger extent from government-provided public goods.

The market price of a unit of the religious goods is the same as in a theocracy, $c$. Therefore the maximization program reads:

$$
\max _{\rho} u(v, \rho, G)=v+\alpha \ln \rho-c \rho+\beta \ln G-\phi \ln \rho G .
$$

The resulting level of religious goods is given by:

$$
\rho^{*}=\frac{\alpha-\phi}{c} .
$$

For $\rho>0$, it is assumed that $\alpha>\phi$. Note that the privately provided level of religious goods declines with increasing religious homogeneity. The reason for this result is the assumed overlap between public and religious goods. Therefore, it cannot be attributed to the provision of religious goods via a state-monopoly, in contrast to private provision, as in Adam Smith; see Coşgel and Miceli (2009, p. 410) for the latter.

Given the private provision of religious goods, an autocratic regime maximizes the following objective function:

$$
U^{A}\left(x^{A}, G^{A}\right)=x^{A}+\mu^{A} G^{A},
$$

where $0<\mu^{A} \leq 1$ indicates the legitimization effect of public goods provision for the autocratic regime. 
Tax revenue (per average citizen) in an autocracy that acts as a Leviathan is given by:

$$
T^{A}=a x^{A}+G^{A} .
$$

From an average citizen's perspective the tax function reads:

$$
T^{A}=v+\alpha \ln \rho^{*}+\beta \ln G^{A}-\phi \ln \left(\rho^{*} G^{A}\right)-\bar{u} .
$$

Setting these tax functions equal, yields the tax-financed private consumption of the autocratic leaders (the winning coalition):

$$
x^{A}=\frac{1}{a}\left(v+\alpha \ln \rho^{*}+\beta \ln G^{A}-G^{A}-\phi \ln \rho^{*} G^{A}-\bar{u}\right) .
$$

The autocratic leaders' (unconstrained) maximization program reads as follows:

$$
\left.\max _{x^{A}, G^{A}} \frac{1}{a}\left(v+\alpha \ln \rho^{*}+\beta \ln G^{A}-G^{A}-\phi \ln \rho^{*} G\right)-\bar{u}\right)+\mu^{A} G^{A} .
$$

The optimum level of the public good is given by:

$$
G^{A}=\frac{\beta-\phi}{1-a \mu^{A}} .
$$

Moreover, the religious goods are provided according to $\rho^{W}=\rho^{*}=\frac{\alpha-\phi}{c}$.

Hence, the quality-adjusted level of public goods and services is, according to Eq. (20), the larger the higher the citizens' preferences for these goods and services, and the less they overlap with (public) religious goods. Furthermore, it is also larger the higher the legitimized population share of autocratic leadership, i.e., the legitimized winning coalition.

\section{Democracy}

The objective function of a democratic government is specified in a similar fashion to the preceding functions:

$$
U^{D}\left(x^{D}, G^{D}\right)=x^{D}+\mu^{D} G^{D},
$$

where $0<\mu^{D} \leq 1$ indicates the legitimization effect of public goods provision for the democratic regime. The objective function contains the private consumption of democratic leaders that is tax-financed, as well as public goods and services which also serve to legitimize democratic leaders. The tax revenue required from an average citizen are given by:

$$
T^{D}=\delta x^{D}+G^{D}
$$

From the average citizens' perspective, the tax function is: 
Table 13 Comparison of public and religious goods provision in different regime types
Regime

Public goods provision, $G$ Religious goods provision, $\rho$

\begin{tabular}{lll}
\hline Theocracy & $G^{R}=\frac{\beta}{1-r \mu^{R}}$ & $\rho^{R}=\frac{\alpha}{c-r \mu^{R}}$ \\
Autocracy & $G^{A}=\frac{\beta-\phi}{1-a \mu^{A}}$ & $\rho^{*}=\frac{\alpha-\phi}{c}$ \\
Democracy & $G^{D}=\frac{\beta-\phi}{1-\delta \mu^{D}}$ & $\rho^{*}=\frac{\alpha-\phi}{c}$ \\
\hline
\end{tabular}

$$
T^{D}=v+\alpha \ln \rho^{*}+\beta \ln G^{D}-\phi \ln \rho^{*} G^{D}-\bar{u} .
$$

For democratic regimes too, it is assumed that religious goods are privately provided, $\rho^{\nu}=\rho^{*}$, and religious goods may overlap with public ones.

Setting the tax equations equal, the following private tax-financed consumption results:

$$
x^{D}=\frac{1}{\delta}\left(v+\alpha \ln \rho^{*}+\beta \ln G^{D}-G^{D}-\phi \ln \rho^{*} G^{D}-\bar{u}\right) .
$$

Incorporating the latter expression for $x^{D}$ into the democratic leadership's objective function, the (unconstrained) maximization program reads:

$$
\max _{G^{D}} \frac{1}{\delta}\left(v+\alpha \ln \rho^{*}+\beta \ln G^{D}-G^{D}-\phi \ln \left(\rho^{*} G^{D}\right)-\bar{u}\right)+\mu^{D} G^{D} .
$$

The optimum level of public goods is given by:

$$
G^{D}=\frac{\beta-\phi}{1-\delta \mu^{D}} .
$$

Hence, the optimal provision of public goods and services, according to Eq. (26), increases with an increasing average preference for public goods and services, $\beta$, and in the share of legitimization-adjusted democratic leaders in the population.

\section{Comparison of public good provision}

In the Table 13, the results of the previous analysis are summarized.

Firstly, theocratic regimes provide larger levels of religious goods than autocratic and democratic regimes. As assumed, there is no overlap between religious and public goods. In addition, religious goods' provision supports the legitimization of the religious leadership. However, this does not necessarily imply that all citizens are equally well-off concerning religious goods, as theocracies may oppress minority religions.

Secondly, autocracies and democracies provide, for the same parameters, the same level of religious goods. Nonetheless, autocracies and even democracies may discriminate against or even suppress minority religions. 
Since the focus of this paper is on the quality of public goods and services, the comparison of public goods and services provision in the model can be used to formulate hypotheses for the empirical analysis. The comparison requires some further assumptions. First of all, the parameters of the above model are assumed to ensure that all levels of public (and religious) goods and services are larger than zero. Next, for the preference and overlap parameters, it is assumed that $\beta>\phi$. Moreover, the above terms $r \mu^{R}, a \mu^{A}, \delta \mu^{D}$ are interpreted as the legitimized religious, autocratic and democratic leadership share in the population. The relationships between these shares are assumed as follows:

$$
\delta \mu^{D}>r \mu^{R} \geq a \mu^{A} .
$$

The first inequality is motivated in accordance with Adam et al. (2011), who argue that the accountability of governments in a democracy is higher than in autocracies, because democratic leaders are elected by voters. This means that the legitimized democratic leadership share is larger than the religious one. The latter is assumed to be larger than or equal to the leadership share of autocracies.

Hypothesis 1 The quality of public goods and services is larger in democracies than in both theocracies and autocracies. In addition, the quality of public goods and services in theocracies is either larger than or equal to the level in autocracies.

Hypothesis 1 follows directly from the analysis above:

$$
\begin{aligned}
& G^{R} \geq G^{A} \text { because of } r \mu^{R} \geq a \mu^{A} \text { and } \beta \geq \beta-\phi . \\
& G^{D}>G^{A} \text { because of } \delta \mu^{D}>a \mu^{A} . \\
& G^{D}>G^{R} \text { if } \frac{\beta}{\beta-\phi}<\frac{1-r \mu^{R}}{1-\delta \mu^{D}} .
\end{aligned}
$$

Therefore: $G^{D}>G^{R} \geq G^{A}$.

Hypothesis 2 In autocratic and democratic regimes, the quality of public goods and services increases with increasing religious diversity:

$$
\frac{\partial G^{A}}{\partial \phi}=-\frac{1}{1-a \mu^{A}}<0, \frac{\partial G^{D}}{\partial \phi}=-\frac{1}{1-\delta \mu^{D}}<0 .
$$

Hypothesis 2 results from Eqs. (20) and (26).

\section{References}

Abdoh-Tabrizi E, Shahi A (2020) Iran's 2019-2020 demonstrations: the changing dynamics of political protests in Iran. Asian Aff 51:1-41

Adam A, Delis MD, Kammas P (2011) Are democratic governments more efficient? Eur J Polit Econ 27:75-86 
Alesina A, Zhuravskaya E (2011) Segregation and the quality of government in a cross section of countries. Am Econ Rev 101:1872-1911

Alesina A, Devleeschauwer A, Easterly W, Kurlat S, Wacziarg R (2003) Fractionalization. J Econ Growth 8:155-194

Anckar C (2011) Religion and democracy. A worldwide comparison. Routledge, London

Bardhan P, Mookherjee D (2000) Capture and governance at local and national levels. Am Econ Rev 90:135-139

Barrett DB, Kurian GT, Johnson TM (2001) World Christian Encyclopedia: a comparative survey of churches and religions in the modern world, 2nd edn. Oxford University Press, Oxford

Barrios S, Schaechter A (2008) The quality of public finance and economic growth. Directorate-General Economic and Financial Affairs, Working Paper

Barro RJ, McClearly RM (2003) Religion and economic growth across countries. Am Sociol Rev 68:760-781

Barro RJ, McClearly RM (2005) Which countries have state religions? Q J Econ 120:1331-1370

Berggren N, Bjørnskov C (2013) Does religiosity promote property rights and the rule of law? J Inst Econ 9:161-185

Berman E, Laitin DD (2008) Religion, terrorism and public goods: testing the club model. J Public Econ 92:1942-1967

Besley T, Burgess R (2002) The political economy of government responsiveness: theory and evidence from India. Q J Econ 117:1415-1451

Besley T, Ghatak M (2003) Incentives, choice, and accountability in the provision of public services. Oxf Rev Econ Policy 19:235-249

Besley T, Ghatak M (2006) Public goods and economic development. In: Banerjee AV, Bénabou R, Mookherjee D (eds) Understanding poverty. Oxford University Press, Oxford

Besley T, Pande R, Rahman L, Rao V (2004) The politics of public good provision: evidence from Indian local governments. J Eur Econ Assoc 2:416-426

Binet M-E, Facchini F (2011) Religious freedom in the world: a quantitative approach. Association for the Study of Religion, Economics \& Culture, ASREC Annual Meeting, Crystal City, Washington

Bjørnskov C, Rode M (2020) Regime types and regime change: a new dataset on democracy, coups, and political institutions. Rev Intern Organ 15:531-551

Blair G, Cooper J, Coppock A, Humphreys M, Sonnet L (2018) estimatr: fast estimators for design-based inference. R package version 0.14. https://CRAN.R-project.org/package=estimatr. Accessed 8 Aug 2020

Bovaird T, Löffler E (2003) Evaluating the quality of public governance: indicators, models and methodologies. Int Rev Adm Sci 69:313-328

Boyer P (1992) Explaining religious ideas: elements of a cognitive approach. Numen 39:27-57

Boyer P (2001) Religion explained: the human instincts that fashion gods, spirits and ancestors. Heinemann, London

Brennan G, Buchanan J (1980) The power to tax. Cambridge University Press, Cambridge

Bueno de Mesquita B, Smith J, Siverson R, Morrow A (2003) The logic of political survival. The MIT Press, Cambridge

Chadi A, Krapf M (2017) The protestant fiscal ethic: religious confession and Euro skepticism in Germany. Econ Inq 55:1813-1832

Chaudhary L, Rubin J (2016) Religious identity and the provision of public goods: evidence from the Indian Princely States. J Comp Econ 44:461-483

Cheibub JA, Gandhi J, Vreeland JR (2010) Democracy and dictatorship revisited. Public Choice 143:67-101

Coşgel M, Miceli TJ (2009) State and religion. J Comp Econ 37:402-416

Deacon Robert T (2009) Public good provision under dictatorship and democracy. Public Choice 139:241-262

Dima B, Preda C, Dima Ş (2014) Religion and democracy. J Heterodox Econ 1:31-53

Dixit A (2002) Incentives and organization in the public sector. J Hum Resour 37:696-727

Encyclopaedia Britannica (2020) Theocracy. https://www.britannica.com/topic/theocracy. Accessed 2 July 2020

Engineer M (1989) Taxes, public goods, and the ruling class: an exploration of the territory between Brennan and Buchanan's Leviathan and conventional public finance. Public Finance/Finances Publiques 44:19-30

Engineer M (1990) Brennan and Buchanan's Leviathan models. Soc Sci J 27:419-433 
Fox J (2017) Religion and state dataset. http://www.religionandstate.org. Accessed 28 July 2020

Gill A, Lundsgaarde E (2004) State welfare spending and religiosity: a cross-national analysis. Ration Soc 16(4):399-436

Gouda M, Gutmann J (2019) Islamic constitutions and religious minorities. Public Choice. https://doi. org/10.1007/s11127-019-00748-7

Guiso L, Sapienza P, Zingales L (2003) People's opium? Religion and economic attitudes. J Monet Econ 20:225-282

Hausken K, Martin CW, Plümper T (2004) Government spending and taxation in democracies and autocracies. Const Polit Econ 15:239-259

Heath WC, Waters MS, Watson JK (1995) Religion and economic welfare: an empirical analysis of state per capita income. J Econ Behav Organ 27:129-142

Helliwell JF, Huang H (2008) How's your government? International evidence linking good government and well-being. Br J Polit Sci 38:595-619

Hillman AL, Potrafke N (2018) Economic freedom and religion. Public Finance Rev 46:249-275

Hlavac M (2018) stargazer: well-formatted regression and summary statistics tables. R package version 5.2.1. https://CRAN.R-project.org/package=stargazer. Accessed 8 Aug 2020

Hungerman DM (2005) Are church and state substitutes? Evidence from the 1996 welfare reform. J Public Econ 89:2245-2267

Kammas P, Sarantides V (2019) Do dictatorships redistribute more? J Comp Econ 47:176-195

Kasper W, Streit ME, Boettke PJ (2012) Institutional economics, 2nd edn. Edward Elgar, Cheltenham

Kaufmann D, Kraay A, Mastruzzi M (2010) The worldwide governance indicators: methodology and analytical issues. World Bank Policy Research Working Paper No. 5430. https://ssrn.com/abstr act $=1682130$. Accessed 28 July 2020

Kilinç R, Wagner CM (2015) Micro-foundations of religion and public goods provision: belief, belonging, and giving in Catholicisms and Islam. Politics Relig 8:718-744

Kuran T (2001) The provision of public goods under Islamic law: origins, impact, and limitations of the Waqf system. Law Soc Rev 35(4):841-898

Kuran T (2004) Why the Middle East is economically underdeveloped: historical mechanisms of institutional stagnation. J Econ Perspect 18(3):71-90

Kuran T, Sandholm WH (2008) Cultural integration and its discontent. Rev Econ Stud 75:201-228

Lacroix S (2019) Saudi Arabia and the limits of religious reform. Rev Faith Int Aff 17:97-101

Lake DA, Baum MA (2001) The invisible hand of democracy. Comp Polit Stud 34:587-621

Lehmann D (2005) The cognitive approach to understanding religion. Arch Sci Soc Relig 131-132:199-213

Lizzeri A, Persico N (2001) The provision of public goods under alternative electoral incentives. Am Econ Rev 91:225-239

Mulligan CB, Gil R, Sala-i-Martin X (2004) Do democracies have different public policies? J Econ Perspect 18:51-74

Öktem KG, Erdoğan C (2018) Between welfare state and (state-organised) charity: How Turkey's social assistance regime blends two competing policy paradigms. University of Bielefeld, How 'Social' is Turkey? Working Paper No. 2

Okulicz-Kozaryn A (2010) Religiosity and life satisfaction across nations. Ment Health Relig Cult 13:155-169

Owen AL, Videras JR (2007) Culture and public goods: the case of religion and the voluntary provision of environmental quality. J Environ Econ Manag 54:162-180

Pew Research Center (2014) Table: Religious Diversity Index Scores by Country. https://www.pewforum. org/2014/04/04/religious-diversity-index-scores-by-country/. Accessed 28 July 2020

Plümper T, Martin CW (2003) Democracy, government spending, and economic growth: a political-economic explanation of the Barro-effect. Public Choice 117:27-50

Pollack D, Steckel S, Althoff G (2013) Differenzierung von Religion und Politik im Mittelalter. Frühmittelalterliche Studien. Jahrbuch des Instituts für Frühmittelalterforschung der Universität Münster 47:273-396 (with English abstracts)

R Core Team (2019) R: a language and environment for statistical computing. R Foundation for Statistical Computing, Vienna. https://www.R-project.org/. Accessed 28 Aug 2020

Searle JR (2010) Making the social world. The structure of human civilization. Oxford University Press, Oxford 
Theodorou AE (2014) In 30 countries, heads of state must belong to a certain religion. http://www.pewre search.org/fact-tank/2014/07/22/in-30-countries-heads-of-state-must-belong-to-a-certain-religion/. Accessed 27 Jan 2019

Walsh K (1991) Quality and public services. Public Adm 69:503-514

Weber M (1905) The protestant ethic and the spirit of capitalism. Hypertext version: http://xroads.virgi nia.edu/ HYPER/WEBER/cover.html. Accessed 19 Jan 2019

Wintrobe R (1998) The political economy of dictatorship. Cambridge University Press, Cambridge

Publisher's Note Springer Nature remains neutral with regard to jurisdictional claims in published maps and institutional affiliations. 